\title{
STRUCTURAL APPROACHES TO THE PROBLEM OF TELEVISION NETWORK ECONOMIC DOMINANCE
}

\author{
BRUCE M. OWEN*
}

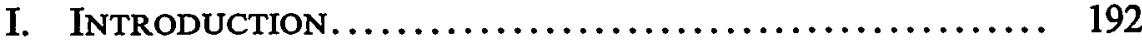

II. AUTHORITY to IMPLEMENT StRUCTURAL Remedies...... 193

III. Structure and Regulation of Television

NETWORKS................................... 198

IV. ECONOMIC ANALYSIS OF NETwORK POWER........... 209

A. Symptoms of Power .......................... 209

B. Sources of Network Power ....................... 211

C. Evaluation Criteria........................... 214

V. Structural Remedies: Description AND

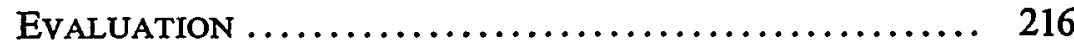

A. Deintermixture ............................. 216

B. The DuMont Plan ........................... 218

C. Divestiture of Network-Owned-and-Operated Stations.. 220

D. Common Carrier Access ........................ 223

E. Promotion of Cable and Pay Television ............. 226

F. Geographic Disintegration ...................... 230

G. Temporal Disintegration ....................... 234

H. The BBC Approach .......................... 236

* B.A., Williams College, 1965; Ph.D., Stanford University, 1970.

The author is Associate Professor, School of Business, and Senior Lecturer, School of Law, Duke University. Mr. Richard C. Finke, J.D., Duke University School of Law, 1979, is co-author of this Article. Useful commeuts and suggestions have been made by Stanley Beseu, David Blank, Philip Kissam, Wesley Magat, David Nicoll, R.E. Park, James Rosse, and Thomas Rowe, none of whom bear any responsibility for remaining errors. The views expressed in this Article are those of the authors. An earlier version of this Article was preseuted to the Federal Trade Commission Symposium on Media Concentration in Washington, D.C., Dec. 14-15, 1978.

THE FOLLOWING CITATIONS WILL BE USED IN THIS ARTICLE:

FCC Notice of Inquiry, Commercial Television Network Practice, 42 Fed. Reg. 4992 (1977) [hereinafter cited as FCC Notice of Inquiry];

R. Noll, M. Peck \& J. McGowan, Economic Aspects of Television Regulation (1973) [hereinafter cited as Nol, PECK \& MCGowan];

B. Owen, J. Beebe \& W. Manning, Television Economics (1974) [hereinafter cited as OWEN, BeEbe \& MaNning];

C. Stering \& T. Haight, The Mass Media: Aspen Institute Guide to CommunicaTION INDUSTRY TRENDS (1978) [heremafter cited as Sterling \& HaIGHT];

Spence \& Owen, Television Programming, Monopolistic Competition, and Welfare, 91 Q.J. EcoN. 103 (1977) [hereinafter cited as Spence \& Owen]. 
I. Temporal Monopoly ......................... 238

J. Nationalization................................. 241

VI. Conclusion .................................. 243

\section{INTRODUCTION}

Clients, suppliers and public interest groups often accuse the three commercial television networks ${ }^{1}$ of having excessive economic power; ${ }^{2}$ the networks and some analysts of network economics, however, deny the existence of sucl a problem. ${ }^{3}$ The latest rcgulatory acknowledgement ${ }^{4}$ of the problem has been by the Federal Communications Commission, whicls lias recently mitiated an mquiry into the matter. ${ }^{5}$

1. American Broadcasting Co. (ABC), 1330 Ave. of the Americas, New York, N.Y.; Columbia Broadcasting Sys., Inc. (CBS), 51 W. 52d St., New York, N.Y.; National Broadcasting Co. (NBC), RCA Bldg., New York, N.Y.

2. E.g., Comments of The Nat'1 Ass'n of Independent Television Producers and Distribs., at 6.8, 38-41, 57-60, FCC Docket No. 21049 (June 1, 1977); Comments of Motion Picture Ass'n of America, Inc., at 2-11, FCC Docket No. 21049 (June 1, 1977); Initial Comments of Nat'1 Citizens Comm. for Broadcasting and Nat'1 Black Media Coalition on the FCC's Network Inquiry, at 2934, 43-57, FCC Docket No. 21049 (June 1, 1977); Westinghouse Broadcasting Co. Petition for Inquiry, Rulemaking and Immediate Temporary Relief, at 30-48 (filed with the FCC Sept. 3, 1976).

3. See, e.g., Crandall, FCC Regulation, Monopsony, and Network Television Program Costs, 3 Bell J. Econ. \& MANAGement SCI. 483 (1972). Professor Crandall applied a television program cost function to data from network television series to establish the proposition that

ofthand attempts to connect the fewness in television network broadcasting to theories of monopoly or monopsony behavior are likely to be unsuccessful. Network broadcasting is far from a typical economic activity since its principal output is donated to viewers while advertisers purcliase rights to address these viewers with counmercial messages. . . . [R]estriction of output is not serious among the current network triopoly, for each firm broadcasts during every hour possible and more than 60 percent of the nation's homes watch this output during prime viewing lours. It is only the FCCthrough its imposition of the Prime Time Rule-which has sought to restrict network output to advertisers and viewers alike by limiting prime-time network broadcasting to three hours per day.

Id. 507. For a discussion of the prime time access rule, see text accompanying notes 85-95 infra. Professor Crandall's point is somewliat weakened by the observation that the network might restrict "output" in some dimension other than "hours." For example, television programming las important qualitative aspects that cannot be measured in terms of hours.

See generally Comments of Nat'l Broadcasting Co., FCC Docket No. 21049 (June 1, 1977). The NBC Comments conclude that network-affiliate relations are "healthy," with sufficient station independence, and that complaints against the networks involve "marketplace issues" which should not concern the FCC. Id. at 232.

4. See, e.g., FCC Notice of Inquiry, Docket No. 20203, 48 F.C.C.2d 1232 (1974) (nse of reruns in prime time by network-owned or affiliated stations); FCC OFFICE OF NETwORK STUDY Second Interim Report, Television Network Program Procurement, Part II, FCC Docket No. 12782 (1965); House Comm. ON INTERSTATE AND Foreign COMMERCE, TELEVISION Network Program Procurement, H.R. Rep. No. 281, 88th Cong., 1st Sess. pt. I (1963); House Comm. on Interstate and Foreign Commerce, Network Broadcasting, H.R. Rep. No. 1297, 85th Cong., 2d Sess. (1958) (Barrow Report); [1941] FCC ANN. Rep. 22-24 (summary of chain broadcasting rules).

5. FCC Notice of Inquiry. 
The purpose of this Article is to examine the implications of various alternative structural approaches to the problem of network economic dominance. Altliough the question of whicll federal governmental entity lias authority to institute the suggested structural remedies is not afforded detailed inquiry in this Article, the law in this area is briefly outlined to establisli that the implementation of sucls remedies is administratively feasible.

The important but thorny problems of proving that network power exists or that the networks abuse that power in their dealings with clients and suppliers have been addressed elsewliere ${ }^{6}$ and are beyond the scope of this Article. Also o1mitted, for reasons stated below, ${ }^{7}$ is a discussion of the various possible behavioral remedies for the problem of network power. ${ }^{8}$

\section{Authority to Implement Structural Remedies}

Assuming the establishment of abuses of econormic and social power, ${ }^{9}$ there appear to be at least four potential sources of structural remedies. Congress undoubtedly could legislate sucl changes, subject to constitutional limitations. Two imdependent agencies, the Federal Communications Commission (FCC) and the Federal Trade Commission (FTC), ${ }^{10}$ could find their authority within the broad, sweeping language of federal statutes and judicial opinions. Finally, the Antitrust

6. See, e.g., ANTItrust Subcomm. OF THE House Comm. on the Judiciary, 85Th CoNG., 1st Sess., Report of the Television Broadcasting Industry PuRsuant to H. Res. 107 (Comm. Print 1957); Possible Anticompetitive Effects of Sale of Network TV Advertising: Hearings on S. Res. 191 Before the Subcomm. on Antitrust and Monopoly of the Senate Comm. on the Judiciary, 89th Cong., 2d Sess. (1966); H. Ashmore, FEAR IN THE AIR-BROAdCASTING AND tHE FIRST AMENDMENT (1973).

Of course, the current FCC Inquiry will provide fresh infornation on these issues. See text accompanying notes $100-07$ infra.

7. See text accompanying notes 116-19 infra.

8. Behavioral and structural remedies are distinguished herein on the same basis as in antitrust law, where relief in civil actions unay consist of money damages or injunction against continued illegal beliavior or of one of the structural "three D's"-divestiture, dissolution or divorceinent. See F. Scherer, Industrial Market Structure and Economic PerformANCE 465-69 (1970). Sce also C. Kaysen \& D. Turner, Antitrust Policy (1965); R. Posner, ANTITRUST LAW (1976). Structural remedies seek to rennove the economic incentive or opportunity to commit illegal or antisocial economic acts. See note 116 infra.

9. See text accompanying notes 108-15 infra.

10. The FTC has jurisdiction over the radio and television broadcasting industries for the purpose of enforcing the relevant provisions of the Federal Trade Commission Act, 15 U.S.C. \&\& 12-27 (1976). FTC Act section 5 and Clayton Act section 7 exempt from FTC jurisdiction common carriers subject to "the Acts to regulate commerce," defined in FTC Act section 4 to include the Federal Communications Act of 1934. Radio and television broadcasters are not common carriers as that term is defined in 47 U.S.C. $\$ 153(\mathrm{~h})(1976)$ and, thus, are not exempt from the FTC's jurisdiction. 
Division of the Justice Department might be able to obtam a structural remedy in the courts.

The FCC derives its authority over radio and television broadcasting froin subchapter III of the Communications Act of 1934. ${ }^{11}$ According to section 303 of the Act:

Except as otherwise provided in this chapter, the Commission from time to time, as public convemence, imterest, or necessity requires, shall-

(a) Classify radio stations;

(b) Prescribe the nature of the service to be rendered by each class of licensed stations and each station within any class;

(i) Have authority to make special regulations applicable to radio stations engaged in cham broadcasting;

(r) Make such rules and regulations and prescribe such restrictions and conditions, not inconsistent with law, as may be necessary to carry out the provisions of this chapter. . . .12

The same "public interest, convenience, or necessity" criteria that govern the FCC's exercise of licensing and rulemaking powers prevail throughout the subchapter. For example, section $316(a)^{13}$ authorizes the FCC to modify station licenses if "in the judgment of the Commission such action will proinote the public interest, convemience, and necessity." 14 In addition, section $307(b)^{15}$ directs the Commission

[i]n considering applications for licenses, and modifications and renewals thereof, .... [to] make such distribution of licenses, frequencies, hours of operation, and of power among the several States and communities as to provide a fair, efficient, and equitable distribution of radio service to each of the same. ${ }^{16}$

Finally, section $312(a)^{17}$ authorizes the FCC to revoke a license for violation of any regulation authorized by the Act.

Delegation of power in such indefinite terms, though commonplace, ${ }^{18}$ begs for administrative and judicial interpretation. Although judicial interpretations to date have upheld the FCC's broad discre-

11. 47 U.S.C. $\$ \S 151-609$ (1976).

12.' 47 U.S.C. $\$ 303$ (1976). Although the Act refers only to radio, television is included as a form of radio transmission and is therefore subject to the entire regulatory scheme. Allen $B$. DuMont Laboratories v. Carroll, 184 F.2d 153, 155 (3d Cir. 1950), cert. denied, 340 U.S. 929 (1951).

13. 47 U.S.C. \& 316(a) (1976).

14. Id. See also 47 U.S.C. $\$ \$ 307(a), 307(d), 309(a), 310$ (1976).

15. 47 U.S.C. \& 307(b) (1976).

16. $I d$.

17. 47 U.S.C. \& 312(a) (1976).

18. K. Davis, Administrative Law 26-27 (3d ed. 1972). 
tionary rulemaking powers, ${ }^{19}$ the general language of these opinions provides little assistance in determining the specific question at hand.

The most comprehensive authoritative statement of the scope of the FCC's powers is Justice Frankfurter's opinion for the majority in National Broadcasting Co. v. United States $(N B C){ }^{20}$ In upholding the FCC's 1941 clrain broadcasting rules, ${ }^{21}$ Justice Frankfurter relied on past decisions and legislative history as the basis for a detailed explanation of the scope of the FCC's authority.

The touchstone provided by Congress was the "public interest, convenience, or necessity," a criterion which "is as concrete as the complicated factors for judginent in suclı a field of delegated authority permit." . . . "This criterion is not to be interpreted as setting up a standard so indefinite as to confer an unlimited power. ... The requirement is to be interpreted by its context, by the nature of radio transmission and reception, [and] by the scope, character, and quality of services ...."

... True enough, the Act does not explicitly say that the Commission shall have power to deal with network practices found inimical to the public interest. But Congress was acting in a field of regulation which was both new and dynamic. "Congress inoved under the spur of a widespread fear that in the absence of governinental control the public interest might be subordinated to inonopolistic domination in the broadcasting field." . . . In the context of the developing problens to whicl it was directed, the Act gave the Commission not niggardly but expansive powers. It was given a comprehensive inandate to "encourage the larger and inore effective use of radio in the public interest," if need be, by making "special regulations applicable to radio stations engaged in chain broadcasting." $\$ 303(\mathrm{~g})(\mathrm{i}) .^{22}$

Many later courts exploring the scope of the FCC's authority merely quote or paraphrase portions of the $N B C$ opinion as the basis of their findings. ${ }^{23}$ Other judicial opinions, though not citing $N B C$, contain equally broad language. ${ }^{24}$ Justice Frankfurter's exposition, therefore, has not been clarified in any significant respect. Because the opinions speak in general language and because they concern FCC orders, behavioral rules and the like, they provide very little guidance in

19. See generally cases cited in notes $20,23-24$ infra.

20. 319 U.S. 190 (1943).

21. See note 71 infra.

22. 319 U.S. at 216-19 (citations omitted).

23. See, e.g., United States v. Midwest Video Corp., 406 U.S. 649, $668-69$ (1972); United States v. Southwestern Cable Co., 392 U.S. 157, 172-73 (1968); United States v. Storer Broadcasting Co., 351 U.S. 192, 203 (1956).

24. See, e.g., Ashbacker Radio Co. v. FCC, 326 U.S. 327, 331 (1945); Greater Boston Television Corp. v. FCC, 444 F.2d 841, 851 (D.C. Cir. 1970). 
determining whether the FCC has the authority to institute structural remedies.

The FTC is the sole entity entrusted with the enforcement of section 5 of the Federal Trade Commission Act, ${ }^{25}$ which declares unlawful "[u]nfair methods of competition in or affecting commerce, and unfair or deceptive acts or practices in or affecting commerce."26 Because the FTC Act was designed "to stop in their incipiency acts and practices which, when full-blown, would violate"27 the Sherman and Clayton Acts, a section 5 violation can be found where practices "conflict with basic pohicies of the Sherman and Clayton Acts even though such practices may not actually violate these laws." 28

The FTC's enforcement power is limited to the issuance of trade regulation rules ${ }^{29}$ and "cease and desist" orders. ${ }^{30}$ The latter usually enjoin future unlawful conduct, although they can be used to effect structural changes. For example, the courts have upheld FTC orders of divestiture based on violations of section 7 of the Clayton Act $^{31}$ and on findings of monopolization. ${ }^{32}$ Also, the FTC is currently seeking to break up the four largest ready-to-eat cereal companies ${ }^{33}$ and the eight largest petroleum companies ${ }^{34}$ for alleged section 5 violations.

Judicial interpretation of the scope of the FTC's remedial powers under the FTC Act is as broad as and as general as that of the Communications Act. The Supreme Court considers the FTC "the expert body to determine what remedy is necessary to eliminate the unfair or deceptive trade practices which have been disclosed. It has wide latitude for judgment and the courts will not interfere except where the remedy

25. 15 U.S.C. $\& 45$ (1976). The FTC shares with the Antitrust Division responsibility for the enforcement of Clayton Act sections 2, 3, 7 and 8, which deal respectively with price discrimination, tying arrangements and requirements.contracts, mergers and interlocking directors. 15 U.S.C. $\$ 21$ (1976). Other agencies are empowered to enforce those statutes in specified situations. Id.

26. Id. \& 45(a)(1) (1976).

27. FTC v. Motion Picture Advertising Serv. Co., 344 U.S. 392, 394-95 (1953).

28. FTC v. Brown Shoe Co, 384 U.S. 316, 321 (1966).

29. 16 C.F.R. $\& 1.8$ (1978). The rules set forth the FTC's interpretation of the substantive requirements of statutes administered by the FTC. Although infrequently rehed upon in antitrust enforcement, the rules have the force of law. L. SulLivan, HANDBOOK OF THE LAW OF ANTITRUST 756-57 (1977).

30. 15 U.S.C. $\$ 45(b)$ (1976). The FTC may seek preliminary injunctions to maintain the status quo until the complaimt is resolved, $i d . \S 45$, and may bring civil actions with penalties of up to $\$ 10,000$ per day for contimuing violations of final orders, $i d . \S 45(l)$.

31. See Seeburg Corp. v. FTC, 425 F.2d 124 (6th Cir.), cert. denied, 400 U.S. 866 (1970); Ekco Prods. Co. v. FTC, 347 F.2d 745 (7th Cir. 1965).

32. See L.G. Balfour Co. v. FTC, 442 F.2d 1 (7th Cir. 1971).

33. [1972] 547 ANTITRUSt \& TRADE Reg. Rep. (BNA) A-3, D-1.

34. [1973] 623 ANTITRUST \& TRADE REg. REP. (BNA) A-1; [1973] 622 ANTITRUST \& TRADE REg. REP. (BNA) A-20. 
selected has no reasonable relation to the unlawful practices found to exist." 35

Other considerations, however, militate against the notion that the FTC can impose the structural remedies considered in this Article. Like the judicial interpretation of the Comunications Act, the sweeping language quoted above would not necessarily support the validity of structural remedies that are both novel ${ }^{36}$ and far reaching. ${ }^{37}$ Furthermore, most FTC orders have been designed to reinedy specific harmful conduct or practices, not a concentrated inarket structure. ${ }^{38}$ The precedential value of court decisions granting the FTC broad reinedial discretion and upholding such orders, therefore, is uncertain when structural remedies are imvolved. The few instances in which a structural remedy has been imposed, e.g., divestiture of an acquired colnpany ${ }_{2}^{39}$ may not serve as precedent when the remedy calls for breaking up an mdustry by creating new firms from existing corporations. ${ }^{40}$ Finally, if the FTC slould atteinpt to apply a shared monopoly analysis to the industry's monopoly power, ${ }^{41}$ one should note that at least one commentator has concluded that the legislative history of the FTC Act limits the application of section 5 to the prevention of specific acts or practices that could lead to monopoly power, and that section 5 was not

35. Jacob Siegel Co. v. FTC, 327 U.S. 608, 612-13 (1946) (emphasis added).

36. The courts may require greater than normal specificity from the FTC in its justification of the imposition of novel remedies. See, e.g., Papercraft Corp. v. FTC, 472 F.2d 927, 933 (7th Cir. 1973); Grand Union Co. v. FTC, 300 F.2d 92, 100 (2d Cir. 1962).

37. In Sherman Act cases, at least, the courts may impose complex structural renedies only when less drastic alternatives are not available. See, e.g., United States v. E.I. duPont de Nemours \& Co., 366 U.S. 316, 327 (1961); Timken Roller Bearing Co. v. United States, 341 U.S. 593, 603 (1951) (Reed, J., concurring). See also O'Connor, The Divestiture Remedy in Sherman Act \& 2 Cases, 13 HARv. J. LeGIS. 687, 714-16 (1976).

38. Until recently, the Antitrust Division was the only agency to challenge industrial structure. L. Sullivan, supra note 29, at 754. The FTC has become more active in this arena with its actions against the ready-to-eat cereal industry and the petroleum industry. See authorities cited in notes 33,34 supra.

39. See cases cited in notes 31,32 supra.

40. For an argument construing a Sherman Act section 2 case to support structural remedics for specific conduct, see Nye, Can Conduct Oriented Enforcement Inhibit Conscious Parallelism?, 44 ANTITRUSt L.J. 206, 229-30 (1975).

41. A shared monopoly exists in a market "where no simgle firm possesses sufficient power to be considered a 'monopolist' but where a relatively few firms achieve monopoly-like prices and thus might be said to possess 'shared' monopoly power." 3 P. AREEDA \& D. TURNER, ANTITRUST LAw 359 (1978). No collusion umong the firms need be alleged; it is assumed that the firms recognize their interdependence and refram from competing in price. The issue is whether such shared monopoly, once proven, violates the Sherman Act section 2 monopolization provision. Id. 360. For a discussion of shared monopoly theory, see id. 359-90.

The FTC has advanced a shared monopoly theory as an alternative theory in its cereal case complaint. [1972] 547 ANTITRUST \& TRADE REG. ReP. (BNA) A-3, D-1. Attorney General Griffin Bell announced that the theory would be used by the Justice Department in the future. N.Y. Times, Apr. 15, 1977, \& D, at 1, col. 1. 
intended to authorize the dissolution of the monopoly power itself. ${ }^{42}$ That commentator also concludes that Supreme Court decisions are consistent with this interpretation of the legislative history. ${ }^{43}$ If accurate, this exclusion of monopoly power from the coverage of section 5 renders structural changes inappropriate unless the FTC establishes that the specific conduct im question can only be remedied through such structural changes. ${ }^{44}$ The conflicting factors thus prevent the drawimg of any definite conclusions as to the FTC's authority in this area.

The Antitrust Division of the Justice Department enforces the Sherman and Clayton Acts through civil proceeding ${ }^{45}$ in the federal district courts, with approximately eighty percent of its caseload disposed of through consent decrees. ${ }^{46}$ In theory, the Antitrust Division can seek a variety of structural remedies because the district courts' equity powers permit broad discretion in formulating remedies to meet the facts of particular cases. ${ }^{47}$ In practice, however, courts have been reluctant to grant structural relief, preferring remedies that are less drastic in form and effect. ${ }^{48}$

\section{Structure and Regulation of Television Networks}

In evaluatimg the implications of various structural alternatives, it is important to consider the effect these alternatives will have on freedom of expression and competition in the marketplace of ideas, as well as their value in terms of conventional welfare economics. ${ }^{49}$ The televi-

42. Kruse, Deconcentration and Section 5 of the Federal Trade Commission Act, 46 Geo. WASH. L. REV. 200, 228-32 (1978).

43. Id. 224-25.

44. Id. 229.

45. 15 U.S.C. $\$ 4$ (1976). The Sherman Act may also be enforced through criminal proceedings. Id. $\$ \S 1-2$.

46. Antitrust Adviser 537 (C. Hills ed. 1971).

47. See, e.g., International Salt Co. v. Umited States, 332 U.S. 392, 400-01 (1947) ("[The district courts] are invested with large discretion to model their judgments to fit the exigencies of the particular case"). See also I. PoMeroy, EQuITY JuRISPRUdence 217 (S. Symons ed. 1941).

48. L. Sullivan, supra note 29, at 672-75 (remedies for Clayton Act section 7 violations); O'Connor, supra note 37, at 707-14 (remedies for Sherman Act section 2 violations).

49. Welfare economics is the application of microeconomic theory to the analysis of costs and benefits of alteruative public policies. There are two fundamental criteria by which policies inay be judged-efficiency and equity. Equity refers to the effects of the policy on the distribution of income or wealth. Efficiency refers to the degree to which scarce economic resources are allocated to their most valuable social uses. A defensible measure of the efficiency of a policy is its effect on aggregate "surplus." Surplus las two components: consumers' surplus is the difference between the price consumers would be willing to pay in order to obtain a particular good or service and the price actually paid. For a theoretical welfare analysis of the structure of the television industry, see Spence \& Owen. For general discussions of welfare economics, see J. DE V. Graaf, Theoretical Welfare Economics (1957); E. Mansfield, Microeconomics: TheORY AND Application 435-64 (2d ed. 1975); E. Mishan, Welfare Economics (1964); 
sion networks are extremely important to what Professor Emerson has called "the system of freedom of expression." The network programs are heavily viewed; ${ }^{51}$ many persons admit to receiving most of their news information from television. ${ }^{52}$ The first amendment role of the television networks creates a public imterest in the supervision of network activities that economic impact alone might not warrant..$^{53}$

The economic role of the television networks is complex. ${ }^{54}$ The networks sell audiences to advertisers on behalf of stations. In addition, the networks purchase programs on behalf of stations from program packagers in Hollywood and elsewhere. Thus, the networks act as purchasing and sales agents for stations, who are their clients, while advertisers are the stations' ultimate customers.

The product sold by the networks is the audience. Programs serve as bait-an intermediate product used to attract audiences. Simce the networks sell the advertising and buy the programs, the stations affiliated with networks receive "compensation" from the networks for "clearmg" the programs. Local stations also sell some of their own advertising and buy some of their own programs, ${ }^{55}$ but most programming durimg prime time, when the potential audience is largest, is network supplied. ${ }^{56}$ Each of the three networks also owns five VHF television stations, generally located in the largest cities in the United

Harberger, Three Basic Postulates for Applied Welfare Economics, 9 J. ECON. LiTERATURe 785 (1971); R. Willig, Welfare Analysis of Policies Affecting Prices and Products (Sept. 1973) (unpublislied report prepared for Center for Research in Economic Growth, Stanford University).

50. T. EMERSON, THE System OF Freedom of Expression (1970). Professor Emerson defines this system as the interrelated set of rights, principles, practices and institutions associated with the present-day concept of free expression. Id. 3-4.

51. Sterling \& Haight 374-79. For example, the average louseliold in 1975 viewed more than 45 hours of television per week, up from 40 lours in 1960. Id.

52. Id. $273-75$. In $1976,64 \%$ of those surveyed said television was their "most frequent source of news." Newspapers were cited by $49 \%$, radio by $19 \%$. Id. 273 . It should be noted, however, that a majority of television news program liours are locally originated (non-network), and sucli programs deal primarily with local events. The issue here is the importance of the networks as sources of national news; this issue is not directly addressed by the data cited.

53. [T] he First Amendment is [not] irrelevant to public broadcasting. On the contrary, it has a major role to play as the Congress itself recognized in $\$ 326$ [of the Communications Act, 47 U.S.C. $\$ 326$ (1970)], which forbids FCC interference with "the right of free speech by means of radio communication. . . ." It is the right of the viewers and listeners, not the right of the broadcasters, which is paramount. . . . It is the purpose of the First Amendment to preserve an uninhibited markctplace of ideas in which truth will ultimately prevail, rather than to countenance monopolization of that market, whether it be by the Government itself or a private licensee.

Red Lion Broadcasting Co. v. FCC, 395 U.S. 367, 389-90 (1969). See generally B. OwEN, EcoNOMICS AND FREEDOM OF EXPRESSION 20-26, 87-122 (1975).

54. See generally Owen, Beebe \& Manning; Noll, Peck \& McGowan.

55. [1978] Broadcasting Y.B. B-174 to B-175; Sterling \& Haight 206-07.

56. The present FCC Inquiry was mitiated by a network-affiliated station group. See note 101 infra and accompanying text. 
States. ${ }^{57}$ Both the network "owned-and-operated" stations and the networks themselves are highly profitable. ${ }^{58}$

The Hollywood program production industry, from which the networks obtaim most of their prime time entertainment programs, ${ }^{59}$ is the same mdustry that produces theatrical motion pictures. The mdustry is highly competitive, with frequent entry of new firms and exit of old firms. ${ }^{60}$ Both the industry and the associated unions complain of network abuses in the area of program supply. ${ }^{61}$

The organic statute of broadcast regulation is the Coinmunications Act of $1934,{ }^{62}$ which was enacted before television existed and has not been amended in any fundamental respect simce that time. ${ }^{63}$ The Act

57. All three networks own VHF stations in New York, Los Angeles and Chicago. ABC owns stations in Detroit and San Francisco; CBS, in Philadelphia and St. Louis; and NBC, in Cleveland and Washington. [1977] 46 Television FACrBooK Services 102-a, 108-a, 112-a. Networks are prohibited froln owning inore than seven TV stations, and no more than five may be in the VHF band. 47 C.F.R. $\$ 76.636(2)$ (1977). The purpose of this regulation is to prevent "such a concentration of control contrary to the public interest, convenience or necessity." Id.

58. In 1977 , the 15 network owned-and-operated stations had coinbined revenues of $\$ 503.5$ million and expenses of $\$ 354.2$ million, for pre-tax profits of $\$ 149.3$ million. The networks themselves had revenues of $\$ 2,581$ million, expenses of $\$ 2,175$ million, and pre-tax profits of $\$ 406$ million. BROADCASTING, Aug. 14, 1978, at 38. The ABC network has becoine highly profitable only in recent years. Moreover, the profitability of the three networks as a group has varied over the years in response to changing economic conditions.

59. Crandall, The Economic Effect of Television Network Program "Ownership," 14 J.L. \& Econ. 385, 388-89 (1971); A.D. Little, Inc., Television Program Production, Procurement, Distribution and Scheduling 1-4 (1969). For descriptions of the program supply indnstry, see OWEN, BeEbe \& Manning 17-35; D. McAlpine, The Television Programming Industry (Jan. 1975) (unpublished report prepared for Tucker, Anthony \& R.L. Day, New York); W. Manning, Jr., The Supply of Prime-Time Entertainment Television Programs (Sept. 1973) (unpublished report prepared for Center for Research in Economic Growth, Stanford University).

60. W. Manning, Jr., supra note 59, at 51-53.

61. See, e.g., FCC Notice of Inquiry, supra note 4; Comments of Motion Picture Ass'n of America, Inc., supra note 2.

News and sports programs are produced by the networks themselves, and most of the daytime programming is produced by or for the networks in New York. W. Manning, Jr., supra note 59 , at 19. Recently, a group of independent producers, directors and writers filed an antitrust complaint against the three inajor networks and their New York owned-and-operated stations, alleging unreasonable restraint of trade in television public affairs and news programs exhibited on the networks. Levitch v. Columbia Broadcasting Sys., Inc., No. 78-4624 (S.D.N.Y., filed Sept. 1978). The plaimtiffs request, inter alia, the court to prohibit exhibition over the networks of any television public affairs program or news documentary produced by the networks. Plamtiffs' Complaint at $35-36$.

62. Commumications Act of 1934, ch. 652, 48 Stat. 1064 (1934) (current version at 47 U.S.C. $\S \S 151-609$ (1976)).

63. Major revisions of the Commumications Act are presently under consideration in Congress. H.R. 3333, 96th Cong., 1st Sess. (1979); BroadCasting, April 2, 1979, at 29-32. Several currently effective amendinents should also be noted: provision that license renewals may be granted "if the Commission finds that public interest, convenience, and necessity would be served thereby," Communications Act Amendments of 1952, ch. 879, \& 5, 66 Stat. 714 (codified at 47 U.S.C. $\$ 307$ (d) (1976)); prohibition of station license transfers except "upon a finding by the 
contains no explicit reference to networks. Broadcast stations-both radio and television-are licensed for a three-year period. ${ }^{64}$ As a matter of law, there is no property right in a broadcast license; ${ }^{65}$ lowever, television licensees are rarely deprived of their right to broadcast, ${ }^{66}$ perhaps because they comply with the FCC's rules, or perhaps because deprivation of the license is sucl a dracomian measure. Television stations are regularly bought and sold on the open market for a price that reflects the economic value of the license as well as the value of the tangible property involved. ${ }^{67}$ Applications for reassignment of broadcast licenses in such cases are generally approved by the FCC as a mat-

Commission that public interest, convenience, and necessity will be served thereby," id. § 8, 66 Stat. 716 (codified at 47 U.S.C. $\$ 310$ (d) (1976)); provision for affording equal time to all candidates for a public office if the station permits one such candidate to use the station, $i d . \S 11,66$ Stat. 717 (codified at 47 U.S.C. § 315(a) (1976)); provision for promotion of noncommercial educational broadcasting and establishment of the Corporation for Public Broadcasting, Public Broadcasting Act of 1967, Pub. L. No. 90-129, 81 Stat. 365 (codified at 47 U.S.C. $\$ \$ 390-99$ (1976)).

At the executive level, President Carter recently abolished the Office of Telecommunications Policy (OTP), which had been responsible for the development and coordination of federal teleconmunications policy. Reorganization Plan No. 1 of 1977, 3 C.F.R. \& 197 (1978). While the President retained responsibility for certain OTP functions, $i d$. $\$ 198$, which were subsequently delegated to other offices and departinents, Exec. Order No. 12046, 43 Fed. Reg. 13349 (1978), the reinaining functions were transferred to the newly created Commerce Department agency, the National Telecommunications and Information Administration, 43 Fed. Reg. 24348 (1978).

64. 47 U.S.C. \& 307(d) (1976).

65. FCC v. National Broadcasting Co., 319 U.S. 239, 247 (1943) (citing FCC v. Sanders Bros. Radio Station, 309 U.S. 470 (1940)). For proposals to create property rights in the electromagnetic spectrum as a ineans of efficiently allocating frequencies, see H. LEVIN, THE lNVISIBLE RESOURCE: Use and Regulation of the Radio Spectrum 85-115 (1971); Presidents Task Force on Communications Policy, The Use and Management of the Electromagnetic Spectrum, StafF PAPER Seven 111-23 (1969); De Vany, Eekert, Meyers, O'Hara \& Scott, A Property System for Market Allocation of the Electromagnetic Spectrum: A Legal-Economic-Engineering Study, 21 StAN. L. Rev. 1499 (1969).

66. In fiscal 1974, for example, the FCC denied license renewals to two radio stations, revoked the licenses of two television stations and designated 20 renewal applications for evidentiary hearing. [1974] FCC ANN. REP. 35-36. In fiscal 1975, however, the FCC disposed of 3,279 license renewal applications, including 341 for television. [1975] FCC ANN. REP. 28. Of these, the FCC denied renewal to 14 stations (mcluding eight Alabama educational stations) and scheduled evidentiary hearings for 17 othcrs. Id. 28, 37. But see Central Fla. Enterprises, Inc. v. FCC, 598 F.2d 37 (D.C. Cir. 1978).

67. H. LEVIN, supra note 65 , at $369-70$. The nunber and average price of television stations sold in the United States over the past 20 years are as follows: 
ter of routine. 68

Licensing of broadcast stations and regulation of their behavior in the first ainendment area are justified by the stations' use of the radio spectrum, a "scarce resource." 69 The validity of the FCC's exercise of regulatory authority over radio (and, by analogy, television) networks was established by the Supreme Court in National Broadcasting Co. $v$. United States, ${ }^{70}$ which upheld the FCC's 1941 chain broadcasting rules. ${ }^{71}$ Scarcity of broadcast frequencies has been the major constitu-

\begin{tabular}{|c|c|c|c|c|c|}
\hline \multicolumn{4}{|c|}{ Number of Transactions } & \multicolumn{2}{|c|}{ Avg. Price of Transaction } \\
\hline Year & TV Only & Radio/TV & Total & TV Only & Radio/TV \\
\hline 1958 & 23 & 17 & 40 & $\$ 730,273$ & $\$ 3,580,742$ \\
\hline 1960 & 21 & 10 & 31 & $1,091,915$ & $2,464,840$ \\
\hline 1962 & 16 & 8 & 24 & $1,437,977$ & $2,352,843$ \\
\hline 1964 & 36 & 20 & 56 & $2,396,513$ & $3,359,288$ \\
\hline 1966 & 31 & 11 & 42 & 986,259 & $2,591,864$ \\
\hline 1968 & 20 & 9 & 29 & $1,679,403$ & $5,284,070$ \\
\hline 1970 & 19 & 3 & 22 & $4,602,846$ & 346,155 \\
\hline 1972 & 37 & - & 37 & $4,240,699$ & - \\
\hline 1974 & 24 & 5 & 29 & $4,957,644$ & $3,960,000$ \\
\hline 1976 & 32 & 1 & 33 & $3,389,364$ & $1,800,000$ \\
\hline 1977 & 25 & 0 & 25 & $5,145,417$ & - \\
\hline 1975 & 51 & 3 & 54 & $5,680,804$ & $10,150,000$ \\
\hline
\end{tabular}

Sterling \& Haight 92; Broadcasting, Feb. 5, 1979, at 34.

68. "Despite the apparent statutory assurance of a free-wheeling inquiry into the relative merit of challenger aud incumbent licensee, the history of Commission practice reveals a strong preference for renewal." Central Fla. Enterprises, Inc. v. FCC, 598 F.2d 37, 42 (D.C. Cir. 1978) (footnote omitted).

69. Columbia Broadcasting Sys., Inc. v. Democratic Nat'l Comm., 412 U.S. 94, 101 (1973); Red Lion Broadcasting Co. v. FCC, 395 U.S. 367, 390 (1969).

We come, finally, to an appeal to the First Amendment. The [FCC] Regulations, even if valid in all other respects, must fall because they abridge, say the appellants, their right of free speech. If that be so, it would follow that every person whose application for a license to operate a station is denied by the Commission is thereby denied his constitutional right of free speech. Freedont of utterance is abridged to many who wish to use the limited facilities of radio. Unlike other modes of expression, radio inherently is not available to all. That is its umique characteristic, and that is why, unlike other modes of expression, it is subject to governmeutal regulation.

National Broadcasting Co. v. United States, 319 U.S. 190, 226 (1943). See also Van Alstyne, The Mobius Strip of the First Amendment: Perspectives on Red Lion, 29 S.C. L. Rev. 539 (1978).

70. 319 U.S. 190 (1943).

71. 47 C.F.R. $\$ 73.658$ (1978). The rules prohibit certain exclusive dealing clauses in the networks' contracts with affiliated stations, shorten the term of affiliation contracts from five years to two, aud prohibit the stations from abdicating their responsibility for program content. The rules require denial of the license application of any station having any arrangement with a network whereby the station is prevented or hindered from broadcasting the programs of another network. Id. \& 73.658(a). Similar rules apply to the following types of arrangements: first, arrangements that preveut other stations from broadcasting the network shows rejected by the apphicant station, id. \& 73.658(b); second, arrangerneuts that subject station scheduling of its own air time to the network's decision on whether or not to utilize that air time, id. \& 73.658(d); third, arrangements that prevent or hinder the station's exercise of its right to reject network programs, 


\section{tional rationale for regulation. ${ }^{72}$}

Although the courts consistently have assumed that the radio spectrum is a scarce resource, economists criticize the assumption that the spectrun is, or need be, in scarcer supply than other physical means of expression under the first amendment. ${ }^{73}$ Thus, Professor Coase argues

id. $\$ 73.658(\mathrm{e})$; or fourth, arrangements that prevent or hinder the station from fixing or altering its rates for the sale of broadcast time, $i d . \S 73.658(\mathrm{~h})$.

72. A different rationale was invoked recently by the Supreme Court to justify FCC regulation of broadcasts containing obscene or indecent language. In FCC v. Pacifica Foundation, 438 U.S. 726 (1978), a New York radio station broadcasted a monologue by humorist George Carlin entitled "Filthy Words" at about 2:00 p.m. The monologue contained repetitious usage of language describing sexual or excretory activities and organs. Acting upon a histener complaint, the FCC issued an opinion that histed four cousiderations justifying the special regulatory treatment of broadcasting:

(1) children have access to radios and in many cases are unsupervised by parents; (2)

radio receivers are in the home, a place where people's privacy interest is entitled to extra

deference. . . ; (3) unconsenting adults may tune in a station without any warning that offensive language is being or will be broadcast; and (4) there is a scarcity of spectrum space, the use of which the governinent must therefore license in the public interest. Of special concern to the Commission as well as parents is the first point regarding the use of radio by children.

In re Pacifica Foundation, 56 F.C.C.2d 94, 97 (1975). Based on these considerations, the Commission found the language of the broadcast to be "mdecent" and prohibited by 18 U.S.C. $\$ 1464$ (1976) ("Whoever utters any obscene, imdecent, or profane language by means of radio communication shall be fined not more than $\$ 10,000$ or imprisoned not more than two years, or both").

The Supreine Court rejected Pacifica's constitutional cliallenge to the Commission's order. Because "[s]ome uses of even the inost offensive words are uuquestionably protected" by the first amendment, the Court examined the context in which the "patently offensive" lauguage was used. 438 U.S. at 746 . That context was a radio broadcast and, "of all forms of communication, it is broadcasting that las received the most limited First Amendment protection." Id. at 748. Although the reasons for distinguishing broadcasting "are complex," two were regarded by the Court as relevant in this case-the "uniquely pervasive presence" of broadcasting that confronts citizens even in the privacy of their homes, $i d$., and the fact that children, in whose moral education the parents and the state are interested, have easy access to broadcasting, id. at 749 . Consequently, regulation of indecent broadcasting is permissible. The Court did not mention the effect of the scarcity of broadcast frequencies.

Pacifica has been interpreted to place "the Supreme Court's imprimatur" on the impact rationale, supplanting the scarcity rationale as the primary justification for subjecting broadcasting to different constitutional treatinent. Address by Judge D. Bazelou, "The First Amendment and the New Media'-New Directions in Regulating Telecommunications," at 10, UCLA Communications Law Symposium (Feb. 2, 1979). On the other hand, the indecent language involved in the Pacifica case raised different issues from those decided in cases in which the scarcity rationale was advanced. See Columbia Broadcasting Sys., Inc. v. Democratic Nat'1 Comm., 412 U.S. 94, 101 (1973) (right of broadcaster to refuse to sell editorial advertising time); Red Lion Broadcasting Co. v. FCC, 395 U.S. 367, 387-89 (1969) (validity of FCC's faimess doctrine); National Broadcasting Co. v. United States, 319 U.S. 190, 226 (1943) (validity of FCC's cham broadcasting rules). In fact, the Pacifica Court cited cases dealing with obscenity, not telecommunications, im support of its decision to distinguish broadcasting. The cases cited were Rowan v. Post Office Dep't, 397 U.S. 728 (1970), and Ginsburg v. New York, 390 U.S. 629 (1968). See also Illinois Citizens Comm. for Broadcasting v. FCC, S15 F.2d 397 (D.C. Cir. 1975) (focusing on obscenity aspects of sexually oriented radio shows).

73. See, e.g., H. LEviN, supra note 65, at 15-16, 201-03; Coase, The Federal Communications Commission, 2 J.L. \& EcoN. 1, 12-I7 (1959); Johnson, Towers of Babel: The Chaos in Radio Spec- 
that the proper course for public policy would be to create marketable property rights in the spectrum and abandon regulation. ${ }^{74} \mathrm{~A}$ recent legislative effort to revise the Communications Act would adopt this approaclı witlı respect to radio and television stations. ${ }^{75}$ Curiously, the major Supreme Court decisions upholding the constitutionality of broadcast regulations have involved radio, ${ }^{76}$ where the scarcity argument is weakest. ${ }^{77}$

The development of television as a dominant social force in America prompted the FCC in 1955 to conduct an inquiry into the structure and operation of the television network broadcasting mdustry. The purpose of the inquiry, which culminated in the issuance of the Barrow Report, ${ }^{78}$ was "to determine whether the present operation of television and radio networks and their relationships witll stations and other components of the industry tend to foster or impede the developinent of a nationwide, competitive broadcasting system."79 The ultimate goal of a competitive broadcasting system and federal regulation thereof is the furtlierance of the "public interest." inquiry's stated purpose, the Network Study Staff conductimg the inquiry examined network concentration and control, drew conclusions and offered recommendations witl regard to several network practices. ${ }^{81}$ The Barrow Report was followed several years later by the two-

Irum Utilization and Allocation, 34 LAw \& ConTEMP. ProB. 505, 506-09 (1969); Meckling, Management of the Frequency Spectrum, 1968 WASH. U.L.Q. 26.

74. Coase, supra note 73, at 25-32.

75. H.R. 3333, 96th Cong., Ist Sess. $\$ 431$ (1979). The bill provides that radio station licenses will be granted for an indefinite period of time. After 10 years, the same provision will become applicable to grants of television station licenses. In the interim, such licenses are limited to five years but may be renewed. Id. The licenses would be subject to revocation for licensee violations of the teruns of the license, FCC rules or specified statutes. Id. $\$ 417$.

76. E.g., FCC v. Pacifica Foundation, 438 U.S. 726 (1978); Red Lion Broadcasting Co. v. FCC, 395 U.S. 367 (1969).

77. In 1970, for exainple, over 200 communities in the United States received four or more AM radio stations. STERLING \& Haight 45. Chicago has 38 radio stations broadcasting from within the city limits. [1978] BRoadcasting Y.B. C-62 to 63. New York City has 37 such stations, Los Angeles has 32, Philadelphia has 29, Houston has 25 and Detroit has 23. Id. C-21 to 22, C-107, C-148 to $149, \mathrm{C}-187$ to $188, \mathrm{C}-213$ to 214.

78. H.R. REP. No. 1297, supra note 4.

79. Id. 1. Although the study was initially addressed to both radio and television networks, the Network Study Staff conducting the inquiry concentrated primarily on television broadcasting, including only a brief survey of the radio broadcasting industry. Reasons given for this focus were the urgency of problems in the television industry and limitations of budget and staff. Id. 9 .

80. The "public interest" is a standard that, in effect, provides the FCC with complete discretion to follow its own inclinations and to alter the standard from time to time.

81. The Network Study Staff offered recommendations with regard to affiliation, option time, rates charged to advertisers, compensation arrangements with stations, the "must buy" practice, network representation of stations in national spot sales, and multiple ownership of stations by the networks. 
part Second Interim Report, ${ }^{82}$ which examined the process of television network program procurement. ${ }^{83}$ The purpose of the Second Interim Report was "to determine whether television network policies and practices in prograin procurement impinge the public interest in television broadcast service sought to be protected by the Federal regulatory pattern for broadcasting." 84

After extensive investigation, ${ }^{85}$ the $\mathrm{FCC}$ in 1970 adopted a rule designed to lessen the power of the networks in the market for television programs. ${ }^{86}$ This "prime time access" rule has two parts. The first part attempts to reduce the bargaining power of networks in negotiations with prograin producers by prohibiting the networks from acquir-

Most television stations carrying network programs are independently owned and tied to the network through affiliation contracts. The major criticisin of such contracts was the inclusion, at the networks' insistence, of allegedly restrictive provisions. H.R. REP. No. 1297, supra note 4, at 207. Network "option time" refers to the right reserved to the network to require affiliated stations to broadcast all network programs offered during designated hours. Film syndicators and local stations have attacked option time provisions as unreasonable restraints of trade in violation of the antitrust laws. The networks have defended option time on the ground that it is essential to the functioning of the network broadcasting system. Id. 279. The Network Study Staff recommended prohibition of the option time practice. Id. 398.

Although the FCC prefers to leave the determination of rates and prices to market coinpetition, "compensation arrangements which restrain competition in a manner contrary to the public interest are within the regulatory jurisdiction of the Commission." Id. 448. Concluding that "substantial differences in coinpensation arrangements prevail," the Network Study Staff recommended that the FCC allow public access to the affiliation contracts that stations are required to file, thus providing greater infornation to affiliates. Id. 466-67.

The "must buy" practice required network advertisers to utilize a specified minimun group of affiliated stations. Id. 469. In light of recent developments in antitrust doctrine, the Network Study Staff expressed serious doubts as to the legality of the "must buy" practice. Id. 502-22.

In national spot advertising, the advertiser purchases broadcast time from individual stations across the country rather than froin the networks. Id. 176. Network representation of stations in national spot sales thus competes with the network's attempts to sell its own broadcast time. Id. 528. Although the Network Study Staff found that the networks occupy only a relatively sinall position in the national spot sales business, the potential for restraint of competition led the Staff to recommend the prohibition of the practice. Id. 539-40.

See id. 553-99 (inultiple ownership is currently regulated by 47 C.F.R. $\$ 73.636$ (1978); see note 57 supra); H.R. REP. No. 1297, supra at 401-47 (rates charged to advertisers).

82. H.R. ReP. No. 281, supra note 4; FCC OfFice of Network Study Second INTERIM REPORT, supra note 4.

83. This aspect of the television industry was not covered in the Barrow Report as a result of difficulties in obtaining "coinpetitive business information" froin some independent program producers. H.R. REP. NO. 1297, supra note 4, at 633.

84. H.R. REP. No. 281, supra note 4, at 19.

85. See Mount Mansfield Television, Inc. v. FCC, 442 F.2d 470, 473-76 (2d Cir. 1971).

86. 47 C.F.R. $\$ 73.658(j)-(k)$ (1978). The "prime time access" rule, as these subsections are called, was upheld against network allegations that the rule was arbitrary, overbroad and violative of the first ainendment. Mount Mansfield Television, Inc. v. FCC, 442 F.2d 470 (2d Cir. 1971). Most of the 1975 ainendments to the rule, 50 F.C.C.2d 829 (1975), were also upheld against constitutional cliallenges. National Ass'n of Independent Television Producers \& Distribs. v. FCC, 516 F.2d 526 (2d Cir. 1975). 
ing subsidiary rights ${ }^{87}$ and off-network syndication rights ${ }^{88}$ in prograins purchased by the networks. The networks remain free, however, to produce their own programs and to retaim all rights im such programs. The second part of the rule prohibits network-affiliated stations from broadcasting network programs or network reruns between 7:00 and 8:00 p.m. ${ }^{89}$ Since one-half of that period was generally not programmed by the networks in any event, the effect was to reduce the period of prime time network programming froin 7:30-11:00 p.m. to 8:00-11:00 p.m., a reduction of one-half hour. The purpose of this portion of the rule is to increase the demand by local stations for programs produced by independent Hollywood packagers and distributed through the local syndication market. ${ }^{90}$ Most stations have filled the prime time access

87. No network may "acquire any financial or proprietary right or interest in the exhibition, distribution, or other commercial use" of nonnetwork produced programs. 47 C.F.R. \$ 73.658(j)(1)(ii) (1978). Thus, for example, CBS would not be permitted to acquire any financial interest in the marketing and sale of games, T-shirts, posters, and the like based on "All in the Family" (produced by TAT/Tandem).

88. The networks may not "sell, license, or distribute television programs to television station licensees within the United States for non-network television exhibition or otherwise engage in the business commonly known as 'syndication' within the United States." Id. \$ 73.658(i)(1)(i). Syndication is the sale of programs, usually filmed or taped, directly to local stations by program packagers. While nuany syndicated programs are reruns of movies or network shows, some are firstrun or live programs produced especially for nonnetwork showing. NolL, PECK \& MCGowan 6. It should be noted that the above provision prevents the networks from syndicating their own programs as well as those produced by independent suppliers.

89. [C]ommercial television stations owned by or affiliated with a national television network. . . shall devote, during the four hours of prime tine (7-11 p.m. e.t. and p.t., 610 p.m. c.t. and m.t.), no more than three liours to the presentation of programs from a national network, programs formerly on a national network (off-network programs) other than feature films, or, on Saturdays, feature films . . . .

47 C.F.R. \$ 73.658(k) (1978). Public affairs programs, documentaries, half-hour network news broadcasts and children's programs are among the programs exempted from the rule. Id.

90. "The public interest requires limitation on network control and an increase in the opportunity for development of truly independent sources of prime time programming. Existing practices and structure combined have centralized control and virtually eliminated needed sources of mass appeal programs competitive with network offerings in prime time." F.C.C. Report \& Order, May 7, 1970, 35 Fed. Reg. 7417, 7422 (1970). These conclusions resulted from the Commission's finding of an "unhealthy situation" in which

[o]nly three organizations control access to the crucial prime time evening television schedule. In the top 50 markets, which are the essential base for independent producers to market programs outside the network process, they are at such a serious disadvantage that prime time first run syndicated programing has virtually disappeared. . . . The lack of available prime time on network affiliates adversely affects the capacity of this alternate program source to supply programing for the independent stations, and particularly the still-strnggling UHF independents upon which Congress and the Commission have relied for a fully competitive nationwide television broadcast service. Furthermore, to the extent that close network supervision of so inuch of the Nation's programing centralizes creative control, it tends to work against the diversity of approach which would result from a more independent position of producers developing programs in both network and syndication markets.

Id. (footnotes omitted). See also Noll, PECK \& MCGowan 82-83. 
period with low-cost game shows and similar programs. ${ }^{91}$

Professor Crandall ${ }^{92}$ has argued that the networks do not possess monopsony ${ }^{93}$ power in program markets because they are but one of several groups of customers for entertainment talent and programming. Other buyers include theatrical motion picture exhibitors, legitimate theater, and competing media, such as radio. Regardless of the extent of network monopsony-or, inore accurately, oligopsony ${ }^{94}$-power in program markets, the prime time access rule represents a response to a problem that appears very real to program producers. ${ }^{95}$

The Justice Department brought Sherman Act suits agamst the three networks in 1974, charging them with attempts to monopolize the prograin production market by means of their monopoly of the airwaves. ${ }^{96}$ The gravamen of the complaints and the prayers for rehef are barely distinguishable from the motivation and policy of the prime time access rule. ${ }^{97}$ In addition, a group of motion picture studios filed

91. Initial Comments of Nat'l Citizens Comm. for Broadcasting, supra note 2, at 49. The comments of these public interest groups suggest that instead of decentralizing overall network power, the prime time access rule inay have strengthened such power by reducing the supply of network originated programs. Such a reduction, it is argued, results in increased network bargaining power vis-a-vis program producers and greater demand for prime time advertising minutes. Id. The validity of the latter conclusion, at least, is questionable. There is no reason to beheve that a reduction in prime time commercial minutes will induce inore advertisers to compete for those mimutes. On the contrary, the resulting higher advertising rates will drive soine advertisers to use alternate advertising inedia.

92. Crandall, supra note 3 , at $487-88$.

93. A monopsony is a market structure wherein many sinall sellers offer a good or service to a single buyer. For a discussion of a inonopsony's basic inarket effects, see M. BARRETT, THE THEORY OF MICROECONOMIC POLICY 248-54 (1974). To the extent that the networks collude in their purchasing policies, the market may resemble a monopsony.

94. An oligopsony is a inarket structure wherem many small sellers offer a good or service to a few large buyers. For a discussion of some models of oligopsonistic market behavior, see J. Henderson \& R. QUANDT, Microeconomic Theory 242-43 (2d ed. 1971). Otigopsony is a structural condition that does not necessarily imply cooperative or collusive behavior.

95. See note 61 supra and accompanying text. There is a plausible argument that the troubles perceived by prograin producers are caused by the coinpetitive and risky nature of their own industry rather than the anticompetitive depredations of the networks. 1t is likely that both factors are at work. The program production industry and the closely associated inotion picture industry are well known for their frequent coinplaints of economic harm at the hands of customers, unions, actors and others, and for their litigiousness. Possibly soine of the complaimts are exaggerated. Meaningful financial data concerning the industry and its constitueut firms are simply unavailable.

96. United States v. National Broadcasting Co., [1974] 693 ANTITRUST \& TRADE Reg. ReP. (BNA) A-11.

97. Given the duplication of relief in the antitrust actions and the prime time access rule, oue must assume that the Antitrust Division mistrusted the Commission's resolve in this matter and sought duplicate relief in a forum over which the Commission had no control.

On November 28, 1977, the court entered a consent decree between one of the defendants, NBC, and the government. United States v. National Broadcasting Co., 1978-1 Trade Cas. I 61,855 (C.D. Cal. 1977), approved 449 F. Supp. 1127 (C.D. Cal. 1978). The terms of that agree- 
an antitrust action in $1970,{ }^{98}$ now inactive, ${ }^{99}$ that had the principal aim of eliminating television network participation in the inarket for theatrical motion pictures.

The most recent study of commercial television network practices was announced by the FCC on January $14,1977 .{ }^{100}$ The study was prompted in part by a rulenaking and inquiry petition filed with the FCC by the Westinghouse Broadcasting Company ${ }^{101}$ and by allegations contamed in Departinent of Justice antitrust coinplaimts filed against the three networks. ${ }^{102}$

Both the Westinghouse petition and the antitrust coinplaints are reactions to the alleged dommance of the three major television networks over the commercial television industry. The present FCC study focuses on "the relationship between these networks and their affiliated stations," 103 with necessary inquiry into the alleged anticompetitive ef:fects of network programming on the development of alternative programming sources. ${ }^{104}$ Under the heading of "Network-Affiliate Relations," the FCC Notice of Inquiry sets forth three areas of particular relevance (although, of course, other areas may be discussed): first, the clearance of network programs by local stations and the expansion of network programming; second, the preview of network programs by

ment prohibit NBC from, inter alia, showing more than two and a half hours per week im prime time of programs acquired from sources other than "independent program supphers"; from showing more than eight hours per week in daytime hours, and more than eleven hours per week in fringe hours, of programs acquired from sources other than "independent program suppliers"; from acquiring subsidiary rights in programs; from requiring use of NBC production facilities; from entering into other tie-ins and reciprocal deals; and from including certain options and price escalation clauses in contracts with the independent program producers. 1978-1 Trade Cas. II 61,855 , at $73,582-85$. The opinion defined the different parts of the broadcasting day as follows: "Prime Tine Hours" means 6:00 p.m. to 11:00 p.m. in the Eastern and Pacific time zones; "Daytime Hours" are 9:00 a.m. to 6:00 p.m. in those time zones; and "Fringe Hours" means 11:00 p.m. to 2:00 a.m. and 6:00 a.m. to 9:00 a.m. in the coastal time zones (Central and Mountam time zone hours vary slightly). Id. at 73,581 .

98. Columbia Pictures Indus., Inc. v. American Broadcasting Co., [1970] 482 ANTITRUST \& Trade Reg. ReP. (BNA) A-4.

99. The action has been stayed pending the outcome of the Justice Department's Sherinan Act suit against the three networks. See notes 96-97 supra and accompanymg text. Telephone conversation with Eleanor Fox, Assoc. Prof. of Law, N.Y.U. School of Law (Apr. 16, 1979).

100. FCC Notice of Inquiry.

101. Id. Westinghouse Broadcasting Company (Group W) owns and operates seven AM and FM radio stations and five television stations. [1978] BroADCASTING Y.B. A-44. All five television stations are affiliated with the networks. Westinghouse Broadcasting Co. Petition for Inquiry, supra note 2 , at 1 .

102. FCC Notice of Inquiry.

103. Id. 4992.

104. $I d$. 
affiliated stations; and third, station compensation plans. ${ }^{105}$ The Notice of Inquiry also lists for discussion six categories of relationships between the networks and program supphers. ${ }^{106}$ The networks, program producer associations and public interest groups have filed comments pursuant to the Notice of Inquiry. A special staff was assembled in June 1978 to evaluate the comments and to conduct the mquiry; a report is expected in 1979 or $1980 .{ }^{107}$

\section{Economic Analysis of Network Power}

\section{A. Symptoms of Power.}

Television stations affiliated with the networks and program producers supplying materials to the networks often complam about particular practices or "abuses" that characterize network behavior. ${ }^{108}$ For example, the stations claim that they are madequately compensated for clearances of network programs; that they are given imsufficient opportunity to review programs im advance; and that program schedules have expanded excessively, thereby encroaching on the stations' ability to air profitable local programming. ${ }^{109}$ Suppliers of programs complain that the networks produce, or threaten to produce, their own programs in order to obtain an advantage in price negotiations, ${ }^{110}$ and that the networks demand certain contractual concessions that eliminate the profits froin first-run network sales. ${ }^{11}$

These complaimts of excessive network economic power are paralleled by complaimts that the networks have extensive political, cultural

105. For a discussion of these relations as symptoms of network economic power, see text accompanying notes $108-15$ infra.

106. The six categories are as follows: (1) network financial interests in syndicated programs produced by independent suppliers; (2) productiou of entertainment programs by the networks themselves; (3) contractual tying agreements relating to production facilities and program options; (4) exhibition rights to pilot programs; (5) exhibition rights to network reruns; and (6) relations between program suppliers and network owned-and-operated stations. FCC Notice of Inquiry 4995.

107. BroadCASTING, June 19, 1978, at 34.

108. See FCC Notice of Inquiry; Westinghouse Broadcasting Co. Petition for Inquiry, supra note 2; Comments of Motion Picture Ass'n of America, Inc., supra note 2.

109. FCC Notice of Inquiry 4993-95; Westinghouse Broadcasting Co. Petition for Inquiry, supra note 2 , at $11-27,35-40$.

110. Comments of Motion Picture Ass'n of America, Inc., supra note 2, at 37-40.

111. Id. 6-9. This claim, though undoubtedly true, is nevertheless misleading. The studios can expect some revenue from off-network syndication, both foreign and domestic. Given that fact, and a competitive market, one would not expect the average program to cover its costs from first-run network exhibition.

One example of such a contractual concession is the networks' alleged demand that program producers utilize network-owned production facilities and studios. Id. 35-37. See also FCC Notice of Inquiry 4995. 
and social power in the inarketplace of ideas. ${ }^{112}$ The scarcity doctrine that supports the constitutionality of broadcast regulation is consistent with the notion that the private power of the broadcast industry would be excessive in the absence of regulation. ${ }^{113}$

The only major interest group from wliom complaints about excessive network power are seldoin heard is the advertising industry. The reason for this is that television network advertising represents only a small portion of the advertising market, and most advertisers liave a choice of media. ${ }^{114}$

The debate about network power at the FCC lias generally centered on the syinptoins of that power. The syinptoms consist of particular practices that the FCC fears may have harmful effects on the networks' economic partners. According to the FCC, these practices lamper the independent judgment of the affiliated stations and restrict effective coinpetition in the programming market. ${ }^{115}$ Such restraints are contrary to the "public interest," which the FCC protects.

There are two general approaches to the problem of excessive social, economic or political network power. The first is to limit this power witli procedural safeguards and regulations, which can be described as constraints on beliavior. For example, the FCC's prohibition of certain clauses in network contracts with affiliates and suppliers represents an attempt to bar certain behavioral abuses. The second general approacl is structural and involves the alteration of the economic environment in such a way as to reduce the excessive power. The use of antitrust decrees to break up a inonopoly is an exainple of a structural approach. ${ }^{116}$

112. See, e.g., F. FRIENDLY, THE GOOD GUYS, THE Bad GUYS, AND THE FirST AMENDMENT (1977); J. MANDER, Four ARguments For the Elimination of TELEvision (1978).

113. See Columbia Broadcasting Sys., Inc. v. Democratic Nat'l Comm., 412 U.S. 94, 125 (1973); Red Lion Broadcasting Co. v. FCC, 395 U.S. 367, 387-88, 392 (1969). See generally Van Alstyne, supra note 69.

114. In 1976, expenditures on network advertising accounted for $43 \%$ of all television advertising and nine percent of all advertising expenditures. STERIING \& HAIGHT 129.

115. FCC Notice of Inquiry 4993.

116. Dissolution is a recognized remedy for monopolization violations of section 2 of the Sherunan Act, 15 U.S.C. $\$ 2$ (1976). Standard Oil Co. v. United States, 221 U.S. 1, 77-81 (1911); United States v. Aluminum Co. of America, 91 F. Supp. 333, 344 (S.D.N.Y. 1950). However, as a result of the existence of complex interrelationships among the various components of an industry, the courts and the government have been reluctant to attempt to restructure industries through dissolution. L. Sullivan, supra note 29, at 145-46. For example, in the 25 years after World War II, there were at least five fully litigated cases in which the United States sought dissolution or divestiture decrees. Divestiture decrees were granted in only two of those cases-United States v. Grinnell Corp., 384 U.S. 563 (1966), and United States v. Paramount Pictures, 334 U.S. 131 (1948). E. Rockefeller, ANTITRUSt Questions AND ANSwers 11 (1974). See also F. ScherER, INDUStrial MARket Structure ANd Economic Performance 467 (1970). 
A structural approach, when feasible, is generally more effective than a behavioral approach because behavioral sanctions do not reinove the underlying source of power which, consequently, is likely to inanifest itself in novel ways. The relative economic, social or political positions of the parties are not changed by behavioral remedies; only the ineclianisins by which one party exploits anotlier are altered. The various behavioral remedies enacted by the FCC over the years, beginning with the chain broadcasting rules ${ }^{117}$ in 1943 and ending with the prime time access rule ${ }^{118}$ in 1970 , can be viewed as recurrent efforts to attenuate syinptoms of network power. New syinptoms, lowever, continue to appear. ${ }^{119}$

\section{B. Sources of Network Power.}

What is the source of the networks' alleged excessive economic and first ainendinent power? In a perfectly competitive econoiny, no person or firm has discretionary power. Sucli an econoiny, by assumption, contains no firm or consumer large enouglt to affect the price of any commodity. ${ }^{120}$ Consequently, every firm merely responds to market signals, especially priccs, that are set by a disinterested economic market process. Moreover, internal production decisions, investment decisions, innovation and other activities of firms are not freely undertaken, but are instead compelled by the need to survive in a competitive world. Firms that do not operate efficiently do not survive. ${ }^{121}$

This description of a competitive inarket econony of powerless firms describes neither the real world in general nor the television networks in particular. In the real world, many firms have some degree of economic and social power. Economic power consists of the ability to set prices above costs without fear of attracting competitive responses fron1 rival firms or new entrants. ${ }^{122}$ Social power consists not of the freedom to maximize profits but rather the freedom to spend profits on activities that are discretionary, without fear of stockholder revolts or takeover bids. ${ }^{123}$ Clearly, both types of power are matters of degree.

The networks are in possession of economic power to the extent

117. See note 71 supra.

118. See text accompanying notes $85-91$ supra.

119. For example, coinplaimts have been heard in recent years regarding the networks' use of reruns in prime time, FCC Notice of Inquiry, supra note 4, and option provisions in affiliation contracts, Comments of Motion Picture Ass'n of America, Inc., supra note 2, at 14-25.

120. E. MANSFIELD, supra note 49, at 235.

121. For a more detailed explanation of this basic economic model, see id. at 233-55.

122. L. Sullivan, supra note 29, at 30-34.

123. See B. OWEN, supra note 53, at 4-5; cf. Posner, Book Review, 86 YALE L.J. 567, 571 (1977)(possession of social power by media firms questioned). 
that they can cooperate with one another, because they are not at present seriously threatened with entry by outsiders. Further, this potential for cooperation and resistance to competitive impulses is enhanced by the fact that there are only three networks. Both the networks' freedom from fear of entry and the small number of networks are conditions that have been created and maintained by the FCC. In order to understand this, it is necessary to describe the FCC's television allocations process.

The FCC's decisions regarding the allocation of portions of the radio spectrum to television service were made in the 1940s, before it was clear that television was inore than a novelty. Consequently, a relatively limited allocation was made, and the spectrum that was made available to television was assigned to local communities. ${ }^{124}$ The FCC later attempted to expand the overall quantity of the spectrum allotted to television broadcasting by making a portion of the UHF spectrum available. ${ }^{125}$ The emphasis on locahism was never abandoned. ${ }^{126}$ The benefits of a policy that emphasizes local stations mclude the potential for local interest programs and diverse political control. One of the costs of such a policy is a reduction in the number of choices available to viewers.

After initial experimentation, the FCC allocated twelve VHF channels to television broadcasting. ${ }^{127}$ However, all twelve channels could not be allocated to every city because of the problem of interfer-

124. A television channel requires a band width many times that of a radio channel. Thus, im the only spectrum area thought usable by television-the VHF band-only 12 channels were made available. Channel interference further restricted the number of available channels in any one area. As a result of this technological scarcity (UHF broadcasting was not yet feasible), the FCC opted in 1945 for a system of local station broadcasting, allocating frequencies to a limited number of stations. In 1948, the FCC put a freeze on new station authorizations to prevent "the development of strong vested imterests im an all-VHF system before UHF technology was ready." President's Task Force on Communications Policy, Future Opportunities for TeleviSION-PART I 30-32 (1969).

125. By 1952, advancements in UHF technology permitted the FCC to lift the freeze on new station authorizations and allocate portions of the UHF band. Through such allocation, the Commission hoped to answer demands for an increased number of channels while pursuing its policy of localism. Id. 31-33. This attenpt was not very successful, for reasons that will be explained below. See text accompanying notes 141-49 infra.

126. President's Task Force on Communications Policy, supra note 124, at 25-32. The inportance of locahism persists today. "[T]he Commission in administering the Act and the Courts in interpreting it, have consistently maintained that responsibility for the selection and presentation of broadcast ultimately devolves upon the individual station licensee . . . . FCC Notice of Inquiry 4992 (emphasis added) (citing En Banc Programming Policy Report, 20 R.R. 1901, $1911(1960)$ ).

127. W. EMERY, BROADCASTING AND GOVERNMENT: ResponsibILITIES AND REgulations 113-14 (1961). 
ence. ${ }^{128}$ There must be a reasonable buffer zone or spacing between stations on the saine or adjacent frequencies; ${ }^{129}$ therefore, as the number of communities with locally programmed stations increases, the number of viewing options available for each community decreases. For example, at the opposite extreme, each of the VHF channels might have been made available to a simgle national licensee. ${ }^{130}$ All viewers would have had six or seven viewing options, but only six or seven firms would have controlled the television airwaves, and no local programming would have been possible. Thus, the decision to pursue a policy of localism, combined with the decision to limit the number of VHF channels, resulted in the present pattern of broadcast allocations. Seventy of the largest one hundred cities or inetropoltan areas have at least three VHF stations. ${ }^{131}$ A few of the largest cities have four or more VHF stations, ${ }^{132}$ but only about one-third of the population hives

128. H. LEVIN, supra note 65 , at 341.

129. For example, minimum spacing between stations operating on the same channel ranges from 170 miles in the Northeast to 220 miles in the Gulf region. Id. Similar rules apply to spacing between stations operating on adjacent channels. Note that channels numbered consecutively (e.g., four and five) are not necessarily physically adjaceut (four and five are not). These considerations prevent all 12 VHF channels from being on the air in a given city.

130. See text accompanying notes 157-65 infra (discnssion of DuMont plan). See also NolL, PECK \& MCGOWAN 100-01.

131. There are actually slightly more than 200 television markets as defined by television audience measuring services. [1978] BROADCASTING Y.B. B-1 to B-83. Many of the sinaller markets have fewer than three commercial VHF stations. Id. See also the earlier data in Owen, Cable Television: The Framework of Regulation 351-52, 6 SenaTe CoMm. ON Governmental AFFaIRS, STUDY ON FEDERAL REGULATION app. (1978). The following table provides soine insight into the range of commercial choice by size of market im 1977:

\begin{tabular}{|c|c|c|c|c|}
\hline Market Type & $\begin{array}{l}\text { Top 50 } \\
\text { Markets }\end{array}$ & $\begin{array}{c}\text { Second } 50 \\
\text { Markets }\end{array}$ & $\begin{array}{l}\text { Third } 50 \\
\text { Markets }\end{array}$ & $\begin{array}{l}\text { All Other } \\
\text { Markets }\end{array}$ \\
\hline I & 34 & 3 & 1 & 0 \\
\hline II & 5 & 3 & 0 & 0 \\
\hline III & 6 & 21 & 13 & 3 \\
\hline IV & 5 & 21 & 19 & 1 \\
\hline V & 0 & 1 & 13 & 43 \\
\hline VI & 0 & $i$ & 4 & 14 \\
\hline
\end{tabular}

\footnotetext{
Key: Three network VHF stations plus one or more independent stations.

II. Three network stations (at least one VHF) plus one or more mdependents.

III. Three network VHF stations.

IV. Three network stations (at least one VHF).

V. Fewer than three network VHF stations.

VI. Fewer than three uetwork stations (at least one VHF).

Source: Letter froun David L. Nicoll, FCC Cable Television Bureau, to Bruce Owen (Nov. 3, 1978).
}

132. There are 13 markets with four or more FCC-licensed VHF stations: New York, Chicago, Los Angeles, San Francisco, Washington, D.C., Dallas, Minneapolis-St. Paul, Indianapolis, Seattle-Tacoma, Miami, Phoenix, Portland and Denver. Oweu, supra note 131, at 162. The larg- 
in such cities. ${ }^{133}$

The reason for the limited number of networks is now clear. There are in many cities only three commercial licensees-and hence stations-available for affiliation. ${ }^{134}$ All of these hicensees have become affikated with networks, and consequently, there are only three networks. The network triopoly is a result, therefore, of the FCC policy limiting the number of local stations, and not merely an economic result. If the market were free to reshuffie resources, there would probably be more networks. This Article explores the alternative ways in which such a result might be approximated or simulated through FCC policy. It is first necessary, however, to set out the criteria by which these alternatives will be evaluated.

\section{Evaluation Criteria.}

The structural approaches to the problem of excessive network power will be evaluated on the basis of their effects on freedom of expression, viewer welfare, the economic health of related industries (television stations and program producers) and locahsm. These four criteria are not exhaustive, but seem to encompass most of the important policy goals usually ascribed to the FCC. ${ }^{135}$

Excessive network power is undesirable, presumably, because it reduces freedoin of expression, econormic competition and, therefore, viewer welfare. It is not as easy to justify concern for the economic health of affiliated stations, although the doctrine of Carroll Broadcasting Co. v. $F C C^{136}$ might provide one rationale. This doctrine acknowledges the fact that a station's ability to air unprofitable "mmority" viewpoints may depend on the station being insulated from competition. ${ }^{137}$ The economic health of the program production industry can

est 100 television markets have $87 \%$ of the total population of the country. There are 21 independent VHF stations in these large markets, including eight in New York City, Los Angeles and Chicago. Markets smaller than the top 100 have the remaining $13 \%$ of the population with 11 independent VHF stations. Id. 162-64. A "market" usually covers a viewing area of a dozen or more counties. Id. 164.

133. [1978] BROADCASTING Y.B. at B-80. The 13 markets with four or more commercial VHF stations have about 25 million television households. There are about 73 million television households in the United States. Id.

134. Roughly two-thirds of all TV households are located in cities with four or more commercial licensees, including UHF stations. Id. A network that sought to connect these independent stations would be unable to reach about one-third of the national audience-a considerable economic handicap.

135. See generally Noll, PeCK \& MCGowan 97-128; Coase, supra note 73, at 7-24.

136. 258 F.2d 440, 442-43 (D.C. Cir. 1958).

137. Id. The Carroll case stands for the principle that the FCC's expectation of "public service" programming by station hicensees is contingent on the stations' ability to earn supranornal profits by virtue of the FCC's restraints on competitive entry. Cf. Posner, Taxation by Regulation, 
be associated somewhat loosely with freedom of expression, at least in the sense that greater competition in that mdustry seems supportive of greater ease of expression. In any event, the effect on affiliates and producers of any proposal for change will shed some hight on the political feasibility of the proposal. Localism has long been seen as an important political goal at the FCC, and this is not the place to challenge its validity. The analysis will, however, identify the situations in which localisin conflicts with other goals.

Both freedom of expression and economic competition can be associated with the number of competing media "gatekeepers."138 The gatekeepers control access to the audience. As a practical matter, the networks control the programmers' access to the bulk of the television audience. Hence, an increase in the number of network gatekeepers slould lead to an increase in freedorn of expression. Similarly, an increase in the number of viewing options is generally consistent with an increase in consumer welfare. ${ }^{139}$ The concept of diversity of prograin content is not considered in this analysis because it is arguably a misleading measure of freedom of expression and of economic competition. ${ }^{140}$

The foregoing considerations suggest that the proposals for structural change can be evaluated by analyzing their effect upon four factors: the number of gatekeepers; the number and character of viewing options; revenues and profits of affiliated stations and program suppli-

2 Bell J. ECON. \& MANAGEMENT SCl. 22 (1971) (one of the functions of governmental regulation of private industries is the continued provision of many services at lower rates and in larger quantities than would be offered in an unregulated competitive market).

138. A "gatekeeper" in the field of human communication is an imdividual or group that has the power to determine whether an item of communication, such as a news story or television program, will travel over or through the channel of communication with which the gatekeeper is associated. White, The "Gate Keeper": A Case Study in the Selection of News, 27 JourNaL1SM Q. 383 (1950). An obvious example of a gatekeeper in the television medium is the news director who decides which items will be reported on evening news broadcasts and the extent of the coverage. An early study showed that of the 11,910 column inches of press association wire copy received in one week by a Midwestern morning newspaper, only 1,297 column inches (11\%) were used. Id. 384-85.

139. Both the number and the character of viewing options affect viewer welfare, and thus should be included in any analysis of viewer welfare. OWEN, BEEBE \& MANNING 55; Spence \& Owen 103-06. For a critical survey of other analyses of viewer welfare that ignore the intensity of viewer preferences, see OWEN, BEEBE \& MANNING 49-55.

140. B. Owen, supra note 53, at 20-21, 108-20; Levin, Program Duplication, Diversity, and Effective Viewer Choices: Some Empirical Findings, 61 AM. ECON. REV. 81 (1971); Levin, Book Review, 8 BELL J. ECON. 337 (1977). A totalitarian state totally devoid of freedom of expression might nevertheless produce diverse program content. By contrast, an anarchistic state might be populated with individuals of such homogeneous tastes that there would be no diversity in program content. Similarly, depending on consumer tastes, both monopoly and competition may be consistent with any given degree of diversity in program content. 
ers; and the availability of locally originated programs.

\section{Structural Remedies: Description and Evaluation}

\section{A. Deintermixture.}

In the late 1940s, it became apparent to the FCC that there was an insufficient supply of VHF license assignments for the new and growing television industry. ${ }^{141}$ As a result, new assignments were frozen while the matter was studied. ${ }^{142}$ Finally, in 1952, the Commission allocated eighty-three UHF channels to television broadcasting. ${ }^{143}$ Despite the technical disparity between UHF and VHF signals, the FCC rejected the idea of making the stations in a given community either allVHF or all-UHF. ${ }^{144}$ The result was a mixture ("imtermixture" in FCC jargon) of UHF and VHF stations in most markets. The FCC devoted much of the ensuing decade to dealing with proposals to "deintermix" certam nuarkets ${ }^{145}$ by transferring all of their stations to the UHF band. VHF hicensees naturally objected vigorously to deintermixture, since this would reduce their technical and hence economic advantage. In the end, only five nrarkets were actually deintermixcd. ${ }^{146}$

Deintermixture, or a simple shiftimg of all television stations to the UHF band, would greatly mcrease the potential number of stations in each market. A fourth, or even fifth, network might be possible because there would be a sufficient number of affiliatcs to enable one or two additional networks to reach the entire country. The FCC's failure to accept the UHF solution to the problem of assignment scarcity, therefore, was responsible for the perpetuation of the three-network system. Mucli less drastic nreans were adopted to reduce the "handicap" of UHF stations. These measures included the All-Channel Receiver Act in $1962^{147}$ and the Detent Tuning Rules ${ }^{148}$ a decade later. These efforts, in combination with the growth of cable television, will

141. Noll, Peck \& McGowan 4.

142. See Amendment of Section 3.606 of the Commission's Rules and Regulations (FCC Sixth Report and Order), 41 F.C.C. 148 (1952)(origimally published at 17 Fed. Reg. 3905 (1952)).

143. 41 F.C.C. at $154-58$.

144. Id.

145. E. Krasnow \& L. Longely, The Politics of Broadcast Regulation 96-97 (1973).

146. Id. 97. For example, the Fresno, California market has five stations, all on the UHF band. [1978] BROADCASTING Y.B. B-27. There are currently 14 markets with deintermixed broadcast frequencies. Id. B-6 to B-79.

147. 47 U.S.C. $\S \S 303(\mathrm{~s}), 330$ (1976) (origimally enacted as Act of July 10, 1962, Pub. L. No. 87-529, 76 Stat. 150). The Act authorized the Commission to require that all television sets shipped in interstate commerce be capable of receiving all frequencies allocated by the Commission.

148. 38 Fed. Reg. 29,809 (1973) (codified at 47 C.F.R. $\$ 15.68(d)$ (3) (1978)). The object of the rules was to elimimate the need for routime fine tuning of UHF channels, Comparable Television 
eventually reduce the handicap so that a new network may be viable. ${ }^{149}$

Deintermixture is still, im principle, a pohicy option. It would have less effect today than it would have had in the 1950s because the UHF handicap is not as great today. ${ }^{150}$ However, deintermixture would increase the number of viable UHF stations and the relative attractiveness of existing UHF stations. A fourth network based on existing VHF independents in the largest markets and new or strengthened $\mathrm{UHF}$ independents in other markets would very likely be feasible. ${ }^{151}$

Deintermixture would increase the number of gatekeepers on both the local and national levels by increasmg the number of stations and networks. Also, to the extent that a greater number of competitors would increase competition, the performance of the industry as measured by the attractiveness of the programs might be expected to improve. Deintermixture would, therefore, result in a higher number and quality of viewing options.

The impact of deintermixture on the program production industry seeins clear: there would be additional channel-hours to fill and, therefore, additional demands on the industry's resources. ${ }^{152}$ The level of aggregate spending on television programming would probably also increase, but this is less certain because the level of expenditure on programming by the present network oligopsony may actually exceed the competitive level. ${ }^{153}$

Tuning, 40 F.C.C.2d 675, 675 (1973)(notice of proposed rulemaking), thus eliminating one of the competitive advantages of VHF channels.

149. R. Park, New Television Networks 30 (Dec. 1973) (Rand Corp. Report No. R-1408-MF).

150. Id. 14-15.

151. Contra, id. Park concludes that a new network using the facilities of existing VHF and UHF independent stations would not generate sufficient imcome to affect the fixed costs of running a national network. However, Park's analysis was published in 1973 and was based on still earlier data. Since that time, the UHF lrandicap has continued to decline and the profitability of the network form of operation has greatly increased.

152. It is assumed liere and throughout the Article that, unless otherwise noted, an increase in the number of channels and competitors in the television market would reduce the price of television advertising and would induce greater expenditures on advertising by sponsors. This assumption of elasticity in the demand for television advertising seems reasouable in view of the relatively small proportion of total advertising expenditures that is currently devoted to television advertising. It is a common mistake to assume that the total expenditure by sponsors for television advertising is fixed, or perfectly inelastic, in response to changes in price.

153. The networks have an agreement to fix the number of advertising mimutes sold. $\mathrm{N}_{\mathrm{A}-}$

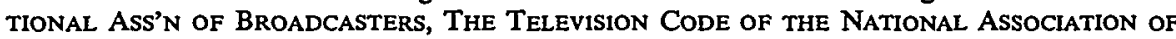
BroADCASTERS (18th ed. 1975). This limiting of supply is roughly equivalent to an agreement to fix prices. Oligopolists in suclı circumstances often compete "excessively" in the quality dimensions of their products. For example, when airline fares were heavily regulated by the Civil Aeronautics Board, the airlines competed by offering qualitative "extras," such as in-flight movies, wider seats and more frequent departures. Networks may similarly compete in program quality. See OWEN, BeEbe \& MANning 91-116. For a discussion of problems with the NAB Code, see 
The effect of deintermixture on individual television stations also seems clear: UHF stations would benefit economically, while VHF stations would be harined. Probably the most important source of economic harm to VHF stations would be the increased nuinber of network-affiliated competitors-an increase froin three to four or five competimg stations in inost inarkets. This would reduce the profits, or expected future profits, of existing VHF affiliates and thus reduce the value of their licenses. ${ }^{154}$ It is arguable, however, that the risk of an FCC policy change such as deintermixture is already reflected in the inarket price of a license, so that no expropriation in fact occurs. Deintermixture can thus be viewed as a maturing contingency for which the "property right" has been discounted by the inarket. Nevertheless, such arguinents go to the question of wliether losses to existimg licensees due to a policy change such as deintermixture ought to be compensated, and not to the reality of a decline in the fiow of profits. ${ }^{155}$ A second source of possible economic harm to existing VHF affiliates would be the cost of physical conversion to UHF transmitters. Since any practical plan for deintermixture would surely be phased in gradually, and since transmitters inust be periodically replaced, this does not seein to pose a serious problem.

Deintermixture, to the extent that it results in new networks, reduces the potential for localism in programming, because stations that formerly were local nonaffiliates, both UHF and VHF, would become affiliates. Network affiliates do less local programming than independent stations, because network prograinming is inore profitable. ${ }^{156}$ Thus, curiously, an increase in the number of local stations might be expected to reduce the voluine of locally produced programming.

\section{B. The DuMont Plan.}

During the early debates on television allocations, the DuMont network suggested to the FCC that the priority given to a policy favoring localism be abandoned in favor of maximizing the number of cities

Note, The Limits of Broadcast Self-Regulation Under the First Amendment, 27 STAN. L. REv. 1527 (1975).

154. The reduction in the inarket value of the license would be the result of the capitalization of the lower expected future profits.

155. For a discussion on the issue of compensation for losses due to governmental policy changes, see Feldstein, Compensation in Tax Reform, 20 NaT'L TAX J. 123 (1976).

156. Noll, PECK \& MCGowan 110-11. To say that network programming is more profitable is roughly equivalent to saying that it receives higher ratings or that it attracts more viewers. 
with at least four (instead of three) VHF assignments. ${ }^{157}$ DuMont was pursuing its own interests in attempting to asseinble enough affiliates to reach a national audience, an endeavor that subsequently failed in 1955. ${ }^{158}$ The DuMont proposal would have required that inore assigninents be inade to large cities, and that there be fewer communities with at least one local station. The price of locahisin was a reduction in the nuinber of viewing options.

Professors Noll, Peck and McGowan have provided an analysis of the benefits that would derive froin a inore drastic version of the DuMont plan in which six viewing options would be available to all viewers. ${ }^{159}$ Such a scheme is practical within the present overall spectruin allocated to television, but would require that nrany existing stations cease to operate as independent local prograin sources. Regional stations reaching very large populations would take their place. There is every reason to suppose that the regional stations would band together to form six national networks, although some regional-interest programming might exist. The effect would be to present every viewer with the equivalent of six network-quality signals.

Studies of consumers' demand for cable television service can be used to measure consumers' valuation of, or willingness to pay for, additional high-quahty television signals. ${ }^{160}$ Noll, Peck and McGowan estimate the increased benefit to viewers from the six-channel DuMont plan to be about one percent of personal incoine, ${ }^{161}$ or about $\$ 15$ billion. ${ }^{162}$ Of course, there would be some costs, aside from the cost of abandoning localism, but these would be outweighed by the benefits. One should note that the FCC regulations do not protect local programming itself - a product in hittle denrand-but rather protect a policy of locahsm, under which local programming is at least theoretically possible. Noll, Peck and McGowan conclude:

The FCC does not defend its emphasis on locahsm on the grounds that it contributes to viewer satisfaction. Rather it holds localism to

157. Id. 101. The FCC flatly rejected the DuMont plan. See FCC Sixth Report and Order, supra note 142, 41 F.C.C. at 171-72.

158. M. Seiden, Who Controls the Mass Media?-Popular Myths and Economic ReALITIES 101 (1974).

159. Noll, PeCK \& McGowan 116-20.

160. Cable subscribers pay for improved local service and for "imported" distant signals. Econometric evaluation of the prices at which cable systems sell various packages of television signals allows one to infer, within statistical limits, estimates of consumer willingness to pay for additional signals of particular types. See id. 27-33, 289-301.

161. Id. 118.

162. This figure is based on 1977 personal mcome estimates at 1977 prices as reported in [1978] ECONOMIC REPORT OF THE President 277, and extrapolated from Noll, PECK \& MCGOWAN 118. 
have major social benefits-enhancing the political process and community cohesion - that have turned out to be illusory. Meanwhile, it ignores the social benefits in reducing the present power of the three networks by providing tliree new competitors. ${ }^{163}$

The Noll, Peck and McGowan version of the DuMont plan would clearly increase the number of national gatekeepers while reducing the number of local ones. Local inedia "monopohes" that are anchored by daily newspapers are often regarded as an important economic, social and political problem. ${ }^{164}$ It is difficult to say whether they should be regarded as a more or less serious problem than national network power, or indeed whether the loss of local television outlets would have a sigmificant practical effect on the ability of daily newspaper monopolists to control advertising prices and public opmion.

For the reasons discussed, it is clear that television viewers would benefit from the implementation of a DuMont plan because the number and quality of viewing options would increase. The fact that cable television customers are willing to pay for these options indicates the desirability to viewers of such a result.

The effect a DuMont plan approach would have on affiliated stations is not clear since a wholesale reallocation and reassignment of the spectrum would be required. Some present licensees would surely benefit from any politically feasible solution, ${ }^{165}$ but others might suffer adverse effects. Since the costs of transition and adjustinent would fall on all the stations, they probably would not favor such a proposal. The effect of the DuMont plan on the prograin production industry is clearly positive, since the number of buyers would increase (thus in all likelihood destroying any oligopsony power in the market) at the same time that the number of chaimel-hours increase, thereby stimulating demand.

\section{Divestiture of Network-Owned-and-Operated Stations.}

It is sometimes suggested in informal discussion of the problem of

163. Id. 120. Defenders of the present system would emphasize the extent of local news coverage. Those who prefer the New York Times as a news source may tend to underrate the value of local TV news.

164. See, e.g., FCC v. National Citizens Comm. for Broadcasting, 436 U.S. 775 (1978). FCC regulations requiring divestiture in "egregious cases" of newspaper-broadcast station cross-ownership were upheld. The regulations were enacted "on the theory that diversification of mass media ownership serves the public interest by promoting diversity of program and service viewpoints, as well as by preventing undue concentration of economic power." Id. at 780. See also W. Baer, H. Geller, J. Grundfest \& K. Possner, Concentration of Mass Media Ownership: Assessing the State of Current Knowledge 60-70 (Sept. 1974) (Rand Corp. Report No. R-1585-NSF).

165. By definition, a "solution" that harmed all existing television station owners could be regarded as politically infeasible. 
excessive network power that the network parent corporations should divest themselves of the fifteen network "owned-and-operated" (O \& O) stations. The $O \& O$ stations, by virtue of their location in the largest television inarkets, are extremely profitable. ${ }^{166}$ If these stations were independent, they might serve as a check on the exercise of network power by acting as a countervailing force in advertising and programming markets. ${ }^{167}$ Additionally, to the extent that network affiliates can be regarded as independent media voices or gatekeepers, the largest cities would experience an increase in freedoin of expression. On the other hand, this proposal would not directly affect the number of networks or the number and type of national network programs.

A finding that $O \& O$ divestiture would benefit the public depends on the potential of the newly independent affiliates to serve as a powerful countervailing force to the networks because of their large audiences. ${ }^{168}$ The most elementary analysis of the economics of the network-affiliate relationship suggests that the networks will have an advantage in cities where the number of potential affiliates is larger than the number of networks, ${ }^{169}$ while the reverse will be true in markets with fewer stations than networks. However, the cities in which the present $\mathrm{O} \& \mathrm{O}$ stations are located tend to be markets with four or

166. In 1977, the 150 \& O stations earned before-tax profits of $\$ 149$ million on revenues of $\$ 504$ million. BroadCASTING, Aug. 14, 1978, at 38.

167. National television advertisers buy both network and "national spot" commercial time. In the national spot market, the stations effectively compete with their own (and other) networks. Network ownership of large-market $O \& O$ stations thus gives the networks an increased share of the overall advertising market. $O \& O$ stations have access to about $22 \%$ of the total viewing audience. Letter from David L. Nicoll, supra note 131. By similar analysis, access by program producers to the first-run syndication market umight be enhanced if the networks did not "own" direct station access to $22 \%$ of the audience. The assumption is that $O \& O$ stations clear more network programs than they would if independently owned. For a discussion of these issues, see R. Noll, Television and Competition (Dec. 14-15, 1978)(unpublished report prepared for the FTC Symposium on Media Concentration, Washington, D.C.). Empirical research by S. Wildman has turned up preliminary indications that $O \& O$ stations charge higher advertismg prices than non$O \& O$ stations otherwise similarly situated. This result suggests that the $O \& O$ stations do exercise monopoly power in advertising markets. See S. Wildman, Vertical Integration in Broadcasting: A Study of Network Owned-and-Operated TV Stations (Dec. 14-15, 1978)(unpublished report prepared for the FTC Symposium on Media Concentration, Washington, D.C.).

168. All affiliates of a network have common interests which could be used to form a coalition with some degree of bargaining power in negotiations with networks. To some extent, this commonality of interest already acts as a restraming influence on the networks' exercise of excessive economic power. Adding the $O \&$ Os as independent members would increase this bargaining power.

169. Besen \& Soligo, The Economics of the Network-Affiliate Relationship in the Television Broadcasting Industry, 63 AM. EcON. REv. 259, 265 (1973). 
more commercial stations. ${ }^{170}$ In such markets, affiliates that fail to please network executives may lose their profitable affiliation contracts to competing independent stations. Therefore, divestiture of $\mathrm{O} \& \mathrm{O}$ stations is unlikely to provide the television marketplace with fifteen economically significant sources of countervailing power.

$O \& O$ divestiture will not decrease the number of local gatekeepers, and it may increase the quahtative value of local programming. ${ }^{171}$ Such a remedy is unlikely to affect the number or quahty of viewing options on the national networks. The aggregate demand for the programming produced in Hollywood would not be affected by $\mathrm{O} \& \mathrm{O}$ divestiture. The composition of this demand, however, might be changed by giving direct access through the syndication market to the $\mathrm{O} \& \mathrm{O}$ stations; syndication demand might increase at the expense of network demand.

It is doubtful that $O \& O$ divestiture would increase the amount of locally produced programming. ${ }^{172}$ In fact, local programming may decline. The $O \&$ Os are now quite sensitive to FCC desires with respect to local public service programming, and may provide more local programming than they would if they were not network-owned. Thus, the public has little to gain, but also little to lose, froin $O \& O$ divestiture.

From a political perspective, $O \& O$ divestiture represents a means of punishing the networks, or at least seeming to punish thein, without actually affecting the structure or performance of the television mdustry in any sigmificant respect. Divestiture would be a syinbolic act of the kind frequently resorted to by policymakers who do not wish to disturb the status quo. ${ }^{173}$

This analysis of the relationship between the networks and the $O$ \& Os implies that the networks would not suffer serious financial harm from divestiture. If there are neither cost savings from joint operation

170. The markets in which $O \& O$ stations are located, the network owner and the number of commercial stations in each city are as follows:

New York (ABC, CBS, NBC)-9 (6 VHF, 3 UHF)

Los Angeles (ABC, CBS, NBC)-12 (7 VHF, 5 UHF)

Chicago (ABC, CBS, NBC)-7(4 VHF, 3 UHF)

Philadelphia (CBS) - 6 (3 VHF, 3 UHF)

Detroit (ABC)-6 (3 VHF, 3 UHF)

San Francisco (ABC)-9 (4 VHF, 5 UHF)

Cleveland (NBC)-3 (all VHF)

Washington, D.C. (NBC) -5 (4 VHF, 1 UHF)

St. Louis (CBS)-6 (4 VHF, 2 UHF).

[1978] Broadcasting Y.B. B-1 to B-79.

171. See note 172 infra.

172. However, there is a possibility that independent affiliates in New York, Los Angeles and Washington would increase local coverage of news and events. Networks now offer as much "local" news from these cities as national news.

173. See generally M. Edelman, Symbolic Uses of Politics (1964). 
of $\mathrm{O} \&$ Os, nor increases in inonopoly power in advertising markets, then the stations will be as profitable when owned by independent hicensees as they are under network ownership. Presumably, potential buyers of the stations would be willing to pay an amount equal to the expected value of the discounted stream of future profits, which amount is equal to the value of the stations to the networks. In fact, the stations may be worth shightly more to others because independent ownership reduces the licensee's visibility as a target for regulatory harassment. If this analysis is correct, then the question remains as to why the networks would resist a proposal for divestiture. Related unanswered questions concern why the networks own the maximum number of VHF stations that they are allowed to own, ${ }^{174}$ and, if the stations can be sold for approximately their value to the network, why the networks are concerned with the retention of these stations. One possible answer is that the stations were acquired at a time when there were cost savings from such ownership, and that they later proved useful for protectimg network profits from public scrutiny. During the period of heavy criticism of network behavior in the 1960s, the networks often pleaded poverty while the $\mathrm{O} \& \mathrm{O}$ stations earned healthy profits. ${ }^{175}$ As to imitial acquisition, station ownership may have been important to the networks in the early days of network competition for affiliates, especially since there were more than three networks in those days. Ownership of stations that served a significant segment of the population, an audience that was thereby denied to competing networks, may have contributed significantly to the success of the three surviving networks.

\section{Common Carrier Access.}

Until the time of the quiz show scandals nearly two decades ago, advertisers and their agencies controlled the content of network television entertainment programs. ${ }^{176}$ Individual programs were typically purchased by a single sponsor and supplied to the network in coumection with the purchase of program-length blocks of time. When scandals arose concerning the rigging of quiz shows, there was much criticisn of excessive sponsor control of content and talent selection.

174. On the other hand, why do the networks not own any UHF stations? Even ownership of five VHF stations does not preclude network ownership of two UHF stations. 47 C.F.R. $\S 73.636(\mathrm{a})(2)(1978)$.

175. For the years $1960-68$, network pre-tax earnings ranged from $\$ 24.7$ to $\$ 78.7$ million, producing a range of profit margins from $4.7 \%$ to $8.9 \%$. In the same years, pre-tax earnings from the 150 \& O stations ranged from $\$ 61.6$ to $\$ 122.4$ million. The profit margins for those stations ranged from $39.6 \%$ to $44.5 \%$. STERLING \& HAIGHT 211 . Of course, other affiliated stations were also profitable. Id.

176. See M. Mayer, About Television 24 (1972). 
At the same time, various economic and technical factors began to militate in favor of mcreased network control of program selection. ${ }^{177}$ Today, the networks are entirely responsible for program selection and content, and individual sponsorship of a program is rare. Thus, for over two decades, control of program selection has been concentrated im a few hands. Libertarians might nevertheless prefer the network system if they believed that the networks would be more courageous in resisting pressures from sponsors than the advertising agencies were under the old system. The present system miglit be preferred by interventionists if the susceptibility of the networks to moral suasion, if not direct regulation, by the FCC was believed to be greater than that of sponsors and advertising agencies.

It is clear that in the early days the networks acted, at least with respect to the class of conventional commercial sponsors, in much the same way as common carriers must act: they sold time to all comers without regard to the content of the message being transmitted. The sponsors and agencies sought to create a large audience for their commercial message, and they attempted to ensure that the entertamment was compatible with the message.

No doubt in the 1950s the networks would have been reluctant to sell time to groups seeking to advocate radical political or social ideas. No doubt they also would have refused to air programs supplied by conventional sponsors'contaming highly unconventional material such as obscenity or pornography. Still, the experience of the 1950s suggests that a systen in whicl the networks' only function is to sell time is both technically and economically feasible. In principle, at least, the buyers of time might be either regulated or unregulated, and the price at which the time would be sold might or miglit not be regulated. ${ }^{178}$ Common

177. Many factors have been cited as affecting this trend. Network advertising rates increased to the point that, in 1964, the cost of a half-hour television series for 39 weeks exceeded the budgets of approximately $87 \%$ of advertisers. 2 A.D. Little, Inc., supra note 59, at 64 . Advertisers recognized that the risk of unexpectedly low ratings was decreased by spreading their commercial messages over several programs rather than relying solely on one half-hour or hour time slot. 1 A.D. Little, Inc., supra at 13-27. The costs of producing and transmitting nighttime television shows rose by $500 \%$ between 1949 and 1959 , and they doubled again between 1959 and 1971 . M. MAYER, supra note 176, at 24. The development of the telecine chain reinoved a technological limitation on the use of fibn on television. Because filmed programs could be more easily reused than taped episodes, "the networks did not have to rely on one advertiser to display an episode twice; instcad a new advertiser could be found." OwEN, BEEBE \& MANNING 20-21. By controlling their schedule, networks could take better advantage of the passivity, see note 181 infra, of television audiences. Advertisers who bought "time periods" failed to take this factor into account. W. Manning, Jr., supra note 59, at 10. Finally, the quiz show scandals resulted in network assumption of inore responsibility for program content. E. BARNouw, TUBE OF PLENTY: THE Evolution of AMERICAN Television 263 (1975).

178. The problem of how to regulate the price at which television networks sell time is not 
carrier regulation of broadcasters is expressly forbidden by the Communications Act of $1934 .{ }^{179}$ Thus, any common carrier access policy would require new legislation.

Today, because of the high cost of television programs (up to $\$ 800,000$ per hour for a dramatic adventure series ${ }^{180}$ ), advertisers generally prefer to buy commercial time on a portfolio of programs rather than risking their entire investment on a single series. As a result, a change to common carrier access rules, prohibiting network control of content, probably would not revive the system of the 1950s. Instead, mtermediaries sucl as advertising agencies or program packagers would probably act as agents, buying network time, finding sponsors and purchasing program rights.

The extent to which the networks can be regarded as more liberal in their policies toward program content, and therefore preferable to sponsors as agents of program control despite the small number of networks, is debatable. In any event, the intermediaries would probably liave characteristics of both, and would preserve the first amendment advantage of a relatively large number of agents for program control.

An important empirical question regarding common carrier access is the extent to whicl economies of scale across prograns exist. A specific inquiry is whether it is less expensive to have program selection and network advertismg sales activities performed by one organization or by inany. No definitive answer is available. If such economies of scale exist and are quantitatively significant, a common carrier access policy would likely result in only a nommal imcrease in the number of gatekeepers. If economies across programs are imsignificant, the increase in the number of program intermediaries will be large. The fact that the networks once acted much like common carriers, and that the change to the present situation can be explained by factors other than economies of scale, suggests-although it does not conclusively prove-that economies of scale across programs are of no great significance.

Although common carrier access to the networks would clearly increase the number of national gatekeepers-from three to however naany intermediaries night emerge - the number of channels would not

trivial. Since audiences vary in size over the day, as well as over programs aired at a given time of day, a fairly complicated price schedule is required in order to clear the inarket. A regulatory system may impose a uniform price ceiling on an industry whose demand varies by time of day; a good example of this is taxicabs. The effect is to create queues at peak periods. It is not clear what form these queues would take in the case of network television.

179. 47 U.S.C. $\$ 153(\mathrm{~h})$ (1976).

180. Broadcasting, Sept. 4, 1978, at 22. 
necessarily be changed, nor would existing spectrum allocations necessarily be realigned. There would apparently be no need for a change in the network-affiliate relationship. The potential for local programming would be unaltered. Viewers would not experience any change in the number of viewing options, and it is not clear that there would be any change in the quality of the options. However, it is true that network programming is now determined witl an eye to "audience flow" and continuity, and this would not be possible witl a decentralized system of program selection. ${ }^{181}$ Programs might therefore be qualitatively different, though not necessarily better or worse. Finally, to the extent that networks exercise oligopsony power in prograin unarkets to the disadvantage of producers, common carrier access with an increased number of intermediaries would destroy this power and improve the economic position of producers. ${ }^{182}$

\section{E. Promotion of Cable and Pay Television.}

In the last decade, there has been an outcry by academic writers against the FCC's restrictive and protectionist policies in the area of cable television and pay television. ${ }^{183}$ Recent court decisions ${ }^{184}$ and

181. Audiences are believed by many to be passive in more than one sense. Network programıners believe that a significant portion of a program's viewing audience is simply a carryover from the preceding program on that network. In other words, the phenomenon of human inertia results in viewers staying tuned to the same channel unless they liave a definite reason to switch. E. EPSTEIN, NewS FROM NowHERE 93-100 (1973). Obviously, this "audience flow" factor can be of great advantage to a network that attempts to boost the sagging ratings of one show by sandwiching it between highly rated programs.

Audiences also may be passive in the sense that, despite significant changes in programming, a large increase in the number of reruns and the advent of color television, the total prime time viewing audience has remained stable (approximately $60 \%$ of television liouseholds) over the last two decades. R. Park, supra note 149, at 5. However, evidence is also available that the total audience can be increased. See R. Park, L. Johnson \& B. Fishman, Projecting the Growth of Television Broadcasting Implications for Spectrun Use 108-09 (Feb. 1976) (Rand Corp. Report No. R-1841-FCC).

182. If the networks were not regulated as to price, see note 178 supra, then common carrier tariff schedules could in principle continue to extract the economic quasi-rents of oligopsony power. These prices would simply be passed through the intermediaries to program producers. In practice, it seems likely that soine substantial measure of the networks' power is exerted through devices that require individual negotiation with program producers in order to effect differential risk sharing and price discrimination arrangements. The necessity of posting a common price schedule would make sucl practices more difficult and might inake price competition more likely.

183. For a "representative" coinpilation of sucl literature, see Midwest Video Corp. v. FCC, 571 F.2d 1025, 1029 n.5 (8th Cir. 1978), affd, 99 S. Ct. 1435 (1979).

184. Id. (FCC's mandatory channel capacity, equipment and access rules for cable television exceeded FCC's authority); Home Box Office, Inc. v. FCC, 567 F.2d 9 (D.C. Cir.), cert. denied, 434 U.S. 829 (1977) (FCC limitations on programming which could be offered to the public held invalid as apphed to pay-cable television); National Ass'n of Regulatory Util. Comm'rs v. FCC, 533 F.2d 601 (D.C. Cir. 1976). 
FCC pohicy changes ${ }^{185}$ have been responsive to this criticism, and the present rules are much less restrictive. ${ }^{186}$ The question remams whether cable television and pay television will result im additional networks or otherwise reduce network power.

Cable television is simply television by wire. ${ }^{187}$ It has two advantages: the number of charmels that can be supplied by wire is limited only by economics and not by airwave crowding or by FCC spectrum policy; and the use of wire provides an opportunity to monitor and charge for use. Over-the-air pay television is possible through the use of scraniblers, but experiments in this area have not yet proved financially successful. ${ }^{188}$ Pay television on cable is growing rapidly and appears successful. ${ }^{189}$ Cable service is a local natural monopoly and, with sufficiently high penetration rates, could displace over-the-air

185. Although cable television penetrated only a small fraction of homes in the mid-1960s, its growth and channel capacity appeared to threaten certain FCC policies, such as the viability of UHF stations and the creation of more local stations. The FCC responded by freezing cable operations in the nation's largest 100 television markets, pending further consideration by the Commission. The freeze on cable television was lifted in 1972, but the FCC adhered to its pohicy of locahisin by imposing three important restrictions: first, importation of distant signals was sliarply limited; second, exclusivity rules required that specific prograins be blacked out; and finally, pay-cable television was limited to showing sports events not generally televised over the air. MacAvoy, Memorandum on Regulatory Reform in Broadcasting, in DEREGULATION OF CABLE TELEVISION 26-27 (MacAvoy ed. 1977).

Soine of the FCC's restrictions liave been deregulated over the past few years. See, e.g., FCC Report and Order, Docket No. 78-206 (Sept. 27, 1978) (deleting requirement of filing certificate of coinphance); FCC Report and Order, 66 F.C.C.2d 380 (1977) (deleting inost franchise standards); FCC Third Report and Order, 62 F.C.C.2d 99 (1976), rev'd on reconsideration, 67 F.C.C.2d 1303 (1978) (permitting carriage of significantly viewed stations without blackout of the duplicated stations); FCC Report and Order, 57 F.C.C.2d 625 (1975) (deleting leapfrogging rules); FCC Order, 54 F.C.C.2d 1182 (1975) (allowing carriage of late-night distant signals after local station sign-off).

186. 47 C.F.R. $\$ 76$ (1978).

187. For a technical description of cable television operation, see PRACTICING LAW InSTItute, Current Developments in CATV 3D 13-43 (G. Christensen chmn. 1973).

188. In the early 1960 s, Zenith Radio Corporation experimented with over-the-air pay television in Hartford, Connecticut. Needing 20,000 subscribers to break even at a revenue per viewer rate of $\$ 106$, the system attracted only 3,000 to 5,000 subscribers. NoLL, PECK \& MCGOWAN 137. Despite their questioning of the validity of some of the Hartford data, Noll, Peck and McGowan concluded that "[a]n extrapolation of the Hartford experience suggests that . . . STV (subscriber television) would be profitable in only a few of the nation's largest inarkets." Id. 140.

There are currently three over-the-air pay television stations broadcasting in the United States. BroAdCASTING, Oct. 2, 1978, at 24. However, a large number of apphications are pending at the FCC, suggesting that entrepreneurs view the future of over-the-air pay television more favorably than history seems to warrant.

189. Pay television on cable reaches 2.5 million subscribers on 789 systems, THE PAY TV NewSLETTER, Oct. 5, 1978, at 1-2, up from only 18,400 subscribers on April 1, 1973, The PAY TV Newsletter, Aug. 13, 1976, at 4. Pay subscribers produce $\$ 250$ million in revenues annually. The Pay TV NewsletTer, Oct. 5, 1978, at 1-2. The 2.5 million subscribers come from a total of 23.5 million households to whon pay-cable service is offered; of these, 7.6 million subscribe to the basic cable service. Id. 
broadcasts.

It seems clear that cable television offers an opportunity to avoid the FCC's restrictions on television spectrum availability, both directly and indirectly, by removing the UHF handicap for the viewers who subscribe to cable. ${ }^{190}$ However, the cost of increasing channel capacity in this way is quite high ${ }^{191}$ and may even be greater than the alternative methods. Moreover, as long as cable depends on improved reception of existing local and distant imported signals, it is unclear that a majority of the population will be "wired."192 Demand for cable is smallest in large cities with good over-the-air reception. ${ }^{193}$ In such places, cable growth depends on the demand for nonbroadcast services, especially special pay television chaimels with movies and sports. Home Box Office, Inc. and other pay television companies already supply such programming to local cable operators, and form what are in effect mininetworks.

In general, there are two constraints on the growth of new networks. The first is the limit on the number of local television stations available to serve as a means of access to the audience; ${ }^{194}$ the second is the availability of revenues to induce firms to enter the network business. ${ }^{195}$ Cable, to the extent that it has a sufficiently large number of subscribers, attenuates the first constramt. The number of channels on the cable is not technically limited or constramed by FCC pohicy. Pay television on cable relieves the second constraint by adding the direct payments of viewers to the demand by advertisers. Viewers seem to value present programming at a price approximately ten times greater then the price actually paid by advertisers. ${ }^{196}$ However, the number of

190. See text accompanying notes $143-50$ supra (discussion of UHF handicap).

191. Where population density is very great, the additional expense of sending television signals over wires, as opposed to over-the-air broadcasting, is easily understood. For example, the average cost per mile of an underground cable system can range from $\$ 6,500$ when cable is laid in sand to over $\$ 100,000$ in the streets of New York City. Estimates of above-ground distribution cost per mile are around \$4,000. CURRent Developments IN CATV, supra note 187, at 65-69.

192. Besen, Mitchell, Noll, Owen, Park \& Rosse, Economic Policy Research on Cable Television: Assessing the Costs and Benefits of Cable Regulation, in Deregulation of CABLE TeleVIsION, supra note 185 , at 45,64 .

193. Id. 56, 61, 64.

194. Since inost stations that would be candidate affiliates for a fourth network would be operating in the UHF band, they would also suffer from reception and tuning problems. R. Park, supra note 149 , at $1-2$.

195. Id. 2.

196. Noll, PeCK \& MCGowan 119; Spence \& Owen 118-19. The consumer surplus associated with the three network channels is estimated to be five percent of personal income. Id. Personal income in 1977 was $\$ 1,536.1$ billion. [1978] ECONOMiC REPORT OF THE PRESIDENT, supra note 162 , at 277 . Therefore, an estimate of consuiners' value of present network television is $\$ 78$ billion. Total advertising receipts for the broadcasting industry in 1977 were $\$ 5.9$ billion. BROADCAsting, Aug. 14, 1978, at 38. 
networks will increase only if there are a large number of cable subscribers, because new networks will be feasible only if they are able to reach all or nearly all of the potential audience. At present, only about nineteen percent of all television households subscribe to cable, and only seventeen percent of these subscribe to pay television services. ${ }^{197}$ There would doubtless be more subscribers if the companies offering cable service were able to offer more and better programming - but the ability to offer more and better programming depends on having more subscribers.

It is possible to conclude fron the preceding analysis that there is a "start-up" or threshold problem with cable. The normal free enterprise solution would be for various firms to invest in the industry with the expectation of losing money in the short run, but earning compensatimg profits later. However, it might be argued that in the case of cable television the investnent required, particularly with respect to the wiring of central cities, is too great for the private sector to undertake. ${ }^{198}$ Thus, an argument might be made for government subsidy or promotion. ${ }^{199}$

Promotion or subsidization of cable television is therefore a possible approach to the problenı of excessive nctwork power. Such a policy has an obvious cost, not just in terms of direct federal expenditure, but also in terins of continued federal imtervention im media regulation. The cable approach also has many benefits.

It is clear that the number of gatekeepers would be significantly increased with respect to individual viewers if and only if the cable operators did not select programs and control program content. Local cable systenis are nonopolies. An increase in the number of gatekeep-

197. National Cable Television Association, Cable Television Development (1978). Thirty-eight percent of those cable subscribers who are offered pay television service subscribe. Letter from David L. Nicoll, supra note 131. See note 189 supra.

198. Telephone companies may be the only firms with the necessary capital and expertise, but current FCC regulations forbid their ownership of cable television systems within their own franchise area. 47 C.F.R. $§ 63.54,63.56$ (1978). Moreover, American Telephone \& Telegraph Co. is barred from this arena by court decree as long as cable systems are not common carriers. United States v. Western Electric Co., 1956 Trade Cas. I 68,246 (D.N.J. 1956). Telephone companies are not, it should be noted, prohibited from providing any sort of hardware or services directly to cable television operators; the prohibition is on direct service to the public.

199. Government assistance for an important fledgling industry is not a novelty in the Umited States. For example, the construction of the American railroads west of the Mississippi River in the late nineteenth century was accomplished only with the aid of substantial federal land grants, federal subsidies and local government assistance. AMERICAN ECONOMIC HISTORY 343-46 (S. Harris ed. 1961). Regardless of whether increased freedoin of expression is as important as was the expansion of the late nineteenth century American econoiny, thus warranting government assistance in the capitalization of the cable TV industry, this freedoun is certainly important enough to support an argument for such assistance. 
ers thus requires not only a policy of promoting cable, but also a common carrier access policy witl respect to cable programming. ${ }^{200}$ Under such a policy, and with no restrictions on pay television on cable channels, the number and quahity of television prograins would increase and viewer welfare would therefore be improved. ${ }^{201}$

Cable growth will necessarily have some harmful effect on VHF network-affiliated stations because of the increased competition. Cable service appears to benefit UHF stations, however, as a result of the improved reception quality that cable affords. ${ }^{202}$ Independent VHF stations also benefit because their programs are imported into other cities, thereby imcreasing the size of their audiences. These imdependent VHF stations may eventually form the nucleus for new networks. ${ }^{203}$ Political opposition to cable from VHF network affiliates, lowever, has been an important source of pressure on the FCC to restrain cable growth. ${ }^{204}$

Cable provides an imcreased long-run opportunity for localism. It does this by fragmenting the audience among so many competing channels that local programs eventually may become at least margmally profitable, and also by using pay television to tap relatively small audiences with relatively intense demands for local-imterest programs, if sucl audiences exist. ${ }^{205}$

Promotion of cable and pay television may, under a common carrier access policy, have a positive effect on all of the dimensions im which the public interest im broadcast regulation is usually measured. But these benefits must be weighed against the costs, both financial and philosophical, of federal subsidization.

\section{F. Geographic Disintegration.}

One straightforward approach to reducing the power of the networks is to reduce the number of stations with which each is affiliated.

200. For discussion of common carrier access to cable, or the so-called "separation policy," see Owen, supra note 131; COMMUMCATIONS SUBCOMM. OF THE HOUSE COMM. ON INTERSTATE AND Foreign Commerce, 94th Cong., 2D Sess., Cable Television: Promise versus Regulatory Performance 89-91 (Comm. Print 1976).

201. Spence \& Owen 124-25; J. Beebe, Institutional Structure and Program Clioices in Television and Cable Television Markets 144-47 (Aug. 1972) (unpublished report prepared for Research Center in Economic Growth, Stanford University). See also Beebe, Institutional Structure and Program Choices in Television Markets, 91 Q.J. ECoN. 15 (1977).

202. Besen, Mitchell, Noll, Owen, Park \& Rosse, supra note 192, at 77; R. Park, supra note 149, at 2.

203. Besen, Mitchell, Noll, Owen, Park \& Rosse, supra note 192, at 51.

204. For examples of affiliatc opposition to cable TV and a discussion of the reasons for such opposition, see MacAvoy, supra note 185, at 33-39.

205. See Spence \& Owen 105. 
A rule to the effect that no network could have affiliation contracts with more than one hundred stations, for example, could increase the number of networks from three to six. ${ }^{206}$

Networks exist because of the economies that can be achieved by spreading prograin expenses over a large audience. The cost of producing a program is not related to the number of viewers. ${ }^{207}$ Thus, a onehour dramatic prograin that costs the network $\$ 400,000$ to produce will have an average cost of four cents per viewer if shown to ten million viewers. If advertisers are willing to pay ten cents per viewer per hour, then a network that reaches only one million viewers with this program will lose $\$ 300,000$ while a network that reaches ten million viewers will make a profit of $\$ 600,000$. Assuming that viewers in different cities prefer similar prograins, these economies of scale will result in the survival of networks of national scope. ${ }^{208}$

The proposal for geographic disintegration would place a public policy limit on the degree to which networks could take advantage of economies of scale. Because the economies would still exist, eacli network could be expected to affiliate with as many stations as were permitted under the applicable statute or regulation. Thus, a proposal to limit each network to fifty stations would probably create twelve networks, and it is likely that the sinall networks would be regionally based. $^{209}$

Geographic disintegration of television networks would change neither the number of stations nor the number of viewing options available to the audience in a given city. Nor would it change the total advertiser deinand for commercial timie. Therefore, the effect of the

206. There are 605 affiliated stations. $A B C$ has 195 , CBS has 198, and NBC has 212. 1978 BroaDCASTING Y.B. D-25, D-34, D-37.

207. Although the cost of producing a program cannot be affected after the fact by the number of viewers, program production costs may be inflated by the cost of attracting audiences. To increase the expected size of a future viewing audience, expenditures for more elaborate sets, higher salaries for "star" talent and advertising must be added to basic production expenses.

208. If viewers' tastes vary regionally, national networks would be at a competitive disadvantage in relation to local and regional broadcasters. The national networks would not be able to attract the sizable audiences required to achieve the economies of scale necessary for the networks' survival. Advertisers would pay less for national commercial minutes, concentrating their budgets on selected regional broadcasts. Local and regional variance in the demand for news reportimg, for example, is one explanation for the absence of a national newspaper in the United States.

209. Regional commonality of taste in programs and savings in transmission costs are imcentives for regional basing of such networks. It should be noted, however, that this effect is probably not very strong, and it is possible that fewer than 12 networks might result if the potential audience to be gamed by connecting smaller stations were much less than the audience of a large network. In other words, there is no guarantee that 12 networks would result naturally from the proposed rule; it might be necessary for the FCC to allocate stations to networks in order to achieve reasonable, commensurate network sizes. 
proposal would be to spread existing revenues ainong a larger nuinber of programs, necessarily resulting in a decline in expenditures per program. To the extent that there is a positive relationship between program cost and prograin quality, quality would decline..$^{210}$

The provision in the FCC's 1972 Prime Time Access Rule restricting network programming in the 7:30-8:00 p.1n. time period is an extreme exainple of disintegration. In effect, existing networks have been prohibited froin affiliating with any stations during those hours. Independent syndicators formed new "mini-networks" by selling their programs to individual stations. Because even the inost successful syndicated prograins reacli fewer stations than do network prograins, and because distribution and selling costs are higher for syndicated programs, the prime time access rule has resulted in a proliferation of game shows and similar low-budget productions. ${ }^{211}$ This result illustrates the trade-off between the economies of the nctwork system and the associated reduction in transaction costs, on the one hand, and the diversity of local tastes on the other. Absent the economies, each station would broadcast the prograins that best "served" local tastes in order to inaximize the size of local audiences. Given the economies, some reduction in audience size is tolerated in exchange for less expensive programs.

In answer to the question wliy there simply are not three new networks during the prime time access period, one possible explanation is that in time there will be. Another answer is that the prime time period is too sliort for the economies of the network system to overcome the risks associated witlı an individual program or to take advantage of economies of scale across prograins. Finally, it nnay simply be a result of tariffs set by American Telephone and Telegraph Coinpany (AT\&T) for television relay service, which establish inuch higher hourly rates for occasional service than for full-time network service. ${ }^{212}$ Thus, the cost of physical interconnection by satellite, nnicrowave or alternative means inay sinply be too great even in the presence of economies in the other dimensions of cost.

Geographic disintegration of television networks would increase the number of gatekeepers on the national level and drastically reduce the political power of the networks. The proposal is technically feasible; it requires no change in spectrum allocations, and the changes in physical interconnection facilities are well within the capability of cur-

210. See note 214 infra and accompanying text (dealing with scarcity rents, program supply and program quality).

211. See note 9 I supra and accompanying text.

212. See, e.g., In re American Tel. \& Tel. Co., 40 F.C.C.2d 90I, 905 (1973). 
rent technology. ${ }^{213}$

The number of viewing options available to consumers would not change, but there would be a drastic reduction in the cost of the programs reaching the imdividual viewers. To the extent that scarcity rents for popular talent comprise a large part of present prograin costs (an empirical question), there need not be any significant change in the qualitative characteristics of programs. ${ }^{214}$ If scarcity rents are not an important component of cost, and if aesthetic quatity is associated with cost, then viewers would suffer because program quahity would dechine.

Geographic disintegration would change the economic or marketing environment in which stations and program producers operate. However, it is not clear that there would be any significant economic effect beyond that which results from the elimination of network ohgopoly and oligopsony power. ${ }^{215}$ Absolute popularity of programs would decline, but the competitive position of individual stations would be unaltered. Therefore, affiliated stations and program producers would benefit froin geographic disimtegration if, and only if, the networks do possess economic power in the relevant markets.

The FCC's policy of promoting local programming would be aided by a policy of geographic disintegration. Since network programs would be lower-budget productions with correspondingly lower absolute audience appeal, locally produced prograins would become relatively nore attractive than they are under the present system, and local stations would broadcast more locally produced programs. ${ }^{216}$

A final note on geographic disintegration: if the dismtegration

213. Football games, for example, are often broadcasted regionally, requiring the construction of regional mini-networks.

214. Scarcity rents are the premium wages that skilled or popular talent commands, over and above the wages that same talent could earn in its next most remunerative occupatiou. Alternatively, scarcity rents are the difference between actual imcome and the income required to retain the talent in this occupation. Since all networks under the new structure would have lower advertising revenues per hour, each would want to pay less for programs. Unless the networks were to purchase common programs, program producers would have to pay less to existing factors of production. If scarcity rents are high, this lowering of wages would not drive these talent factors away into alternative occupations. Hence, qualitative characteristics of programs need not change.

215. Strictly speaking, oligopoly and oligopsony power in the new, smaller geographical markets would remain unchanged; thcre would still be three networks in each market. Whether the position of supphers and customers of the networks would be improved by dealing with a series of regional markets-each with three networks-rather than three national networks is difficult to predict.

216. There is hittle reason to suppose that total advertising expenditures would be affectcd by geographic disintegration. Total expenditures would simply be divided ainong a larger number of programs. The result would be either no change or a decrease in the qualitative superiority of network over local or syndicated programs. 
were sufficiently drastic (for example, twelve networks), it is quite possible that a relatively small number of national suppliers of program material such as news might emerge. In this respect, the program market might be expected to develop along the same line as the syndication and wire service markets in the newspaper industry. ${ }^{217}$ Thus, the proposal for geographic disintegration would not necessarily result in the abolition of national news coverage. The absence of a national press in this country, in contrast to Great Britain and other European nations, ${ }^{218}$ is responsible for the existence of Associated Press (AP), United Press International (UPI) and other smaller wire services, and this absence has not resulted in the exclusion of national material from local or regional newspapers. However, as is the case with AP, UPI and most daily newspapers, geographical disintegration of television networks could actually bring about a situation in which the number of effective or significant suppliers of national news to television stations would be reduced froin three to soine smaller number.

\section{G. Temporal Disintegration.}

Geographic disintegration of television networks, regardless of its benefits, would be costly to society because of the loss of economies of scale realized by distributing program costs over large audiences. Temporal disintegration achieves many of the same benefits as geographic disintegration without sacrificing economies of audience size; instead, whatever economies exist across programs are sacrificed.

The control of the television networks extends, not merely over a chain of stations and a corresponding geographic region, but also over time. In principle, temporal disintegration means one might create new networks simply by limiting, not the number of stations per network, but the number of hours per day that each network could control. Thus, for example, the FCC might proinulgate a rule forbidding any television station licensee froin affiliatimg with any network that broad-

217. Nearly all United States newspapers receive national news stories from one or both of the wire services. Although organizationally different (Associated Press is a cooperative with approximately 8,500 members; United Press International is a private company with approximately 6,000 clients), the two wire services operate in basically the same manner. News reports from members or correspondents are carried to regional offices via leased telegraph circuits. Overseas stories travel to this country, and vice versa, by satellite transmission and transoceanic cable. Editors at the regional offices, located im large metropohtan centers, then transmit all inajor news stories and stories of regional interest to the local newspapers. D. Leroy \& C. SterLing, MASS News: Practices, Controversies, ANd Alternatives 57-63 (1973).

218. Great Britain, for example, has several "national" newspapers, i.e, newspapers published in London and circulated throughout the country. Such newspapers are profitable because of the high concentration of population in a small country, which facilitates rapid distribution. J. MERRILL, C. BRYAN \& M. ALISKy, The Foreign Press 59 (1970). 
casts more frequently than one day per week. In this case, assuming three local stations, there could be twenty-one national networks operating over the course of a week, though still only three at any one time. Another example would be to limit each network to a maximum of one "daypart."219

Given the contimued existence of economies of scale over audiences and the present pattern of spectrum allocation, the effect of temporal disimtegration would be to increase the number of gatekeepers with access to the audience without changing the number of viewing options. In fact, temporal disintegration represents a less drastic form of the proposal for cominon carrier access. ${ }^{220}$ Both proposals would retaim intact the physical chain of stations that comprise a "network" (limited by spectrum pohicy to three networks), while allowing inore than three organizations to control these networks over a period of time. Temporal disintegration is distinguished from cominon carrier access by two features. First, cominon carrier access does not imply any contimuity or regularity of programming or programming orgamzations over time, although soine continuity might be possible; temporal disintegration, on the other hand, presumes that a limited number of more or less permanent organizations would control programming on a regular schedule. Second, it seems more reasonable to regard the temporal disintegration structure as one that might be subject to either direct or self-regulatory control. Cominon carrier access in primciple abolishes gatekeepers altogether, while temporal disintegration inerely mcreases their number.

The question reinains as to why there should be any networks at all under a policy of teinporal dismtegration. After all, the prime time access rule did not create new networks that exist only with regard to the access period. Preservation of the economies of the network system under teinporal disintegration inay require that the maximum number of hours per day that a network imight control should be set at a relatively high level compared to the half-hour provided by the access rule. The period must be long enough to allow the economies of the network systein to overcome the various fixed costs of establishing the network, and long enough to make it possible for the new networks to take advantage of whatever economies of scale may exist across programs. These are important empirical questions that would have to be resolved in the course of designing a policy of teinporal disintegration.

There are two other related issues. The first is whether the FCC

219. A "daypart" is a specific portion of the broadcasting day. Prime time (7:00 p.m. to 11:00 p.m.), for example, can be considered a daypart.

220. See text accompanying notes 176-82 supra. 
should attempt to modify the pohicy of AT\&T with respect to the tariffs for "occasional" use of the television relay service. The second issue is whether a policy of temporal dismtegration should include provisions that would liave the effect of retaining the present physical networks (and some vestigial busmess operations) intact, in order to lower the organizational and transaction costs of the new, temporally limited successor networks. These issues would have to be addressed im formulating a detailed policy of temporal dismtegration.

Analysis of the effect of temporal disintegration on the various policy considerations is included im the preceding discussion of coinmon carrier access. ${ }^{221}$ As with that proposal, teinporal disintegration would bring about an imcrease in the number of gatekeepers and, presuinably, an increase in freedom of expression. There would be no change, lowever, in the number, and probably no change im the quality, of viewing options available to the public. Affiliated stations and program producers both would benefit to the extent that they now suffer from abuses of network economic power. There would be no effect on localisin. Thus, those who might regard the comnon carrier approaclı as desirable in principle but dangerous as an experiment in libertarian idealism miglit prefer temporal disintegration as a sounewhat less risky or inore responsible approach. In practice, temporal dismtegration prevents wealthy eccentrics from imposing their views on the public. ${ }^{222}$ Some, lowever, inay regard sucli an imposition as one of the prices of freedom of expression.

\section{H. The BBC Approach.}

A inajor criticism of the American television network system, and one this Article lias not emphasized heretofore, is that the system produces bland, coinunon-denominator programming that ignores minority tastes and provides excessive duplication of inajority tastes. ${ }^{223}$ Every viewer has his or lier own empirical views on the validity of the

221. See text accompanying notes 181-82 supra.

222. Temporal monopolists would have a contimuing relationship with the public, advertisers and the government that casual users of a common carrier network might lack. The contimuing relationship may produce more "responsible" behavior because of the long-term repercussions of sliort-run decisions. On the closely related idea of "relational contracts," see MacNeil, The Many Futures of Contract, 47 S. CAL. L. Rev. 691, 720-25 (1974).

223. See, e.g., Noli, Peck \& McGowan 49-52, 211-17; Owen, Beebe \& Manning 49-90; Television as a Social Force: New Approaches to TV Criticism 9-21, 63-79 (1975); The TV Establishment: Programming for Power and Profir 137-73 (Tuchman ed. 1974); Beebe, 91 Q.J. Econ. 15 (1977), supra note 201; Spence \& Owen; Steiner, Program Patterns and Preferences, and the Workability of Competition in Radio Broadcasting, 66 Q.J. EcoN. 194 (1952). 
Minow criticism: that American television is a "vast wasteland."224 Enough commentators have thought this criticism vahid to generate quite a large volume of literature seeking to explain the deficiencies of the system. ${ }^{225}$ These commentators agree that the "excessive sameness" in network programming is due to the desire of each network to compete for a putative large-majority-taste audience in order to maximize profits from advertising revenues. Each network, seeking to serve the same audience, produces the same or similar programs.

In contrast to the American system, the British employ an altogether different approach. 226 The British Broadcasting Corporation (BBC) controls more than one television channel. ${ }^{227}$ As a result, even if the $\mathrm{BBC}$ were interested in maximizing audiences for commercial reasons, there would be no point in duplicative programming. A larger total audience would result by programming the channels to appeal to quite different audiences. Professor Peter Steiner, in an early seminal article, ${ }^{228}$ outlined the theoretical basis for superior performance by a monopolist of several channels. His work has simce been extended and generalized by several writers, but the basic conclusion remains intact: under more or less plausible empirical conditions, and with advertising support rather than pay television, competing broadcasters will tend to

224. N. Minow, Equal Time: The Private Broadcaster and the Public Interest 45, 47,52 (1964).

225. See, e.g., J. Beebe, supra note 201; McGowan, Competition, Regulation, and Performance in Television Broadcasting, 1967 WASH. U.L.Q. 499; Rothenberg, Consumer Sovereignty and the Economics of TV Programming, 4 STUD. PUB. CoM. 45 (1962); Steiner, supra note 223; Wiles, Pilkington and the Theory of Value, 73 EcoN. J. 183 (1963).

226. In 1927 the British Broadcasting Company, a consortium of six inajor radio manufacturers, was transformed into the British Broadcasting Corporation. The BBC is financed by license fees on television sets. Portions of the license revenue are diverted to the Post Office, to cover collection expenses, and to the government. The $\mathrm{BBC}$ lias discretion regarding expenditure of the net license revenues.

Overall policy for the BBC is set by the government-appointed, nine-member Board of Governors. Although the government has the power to dismiss a Board nember, this power lias never been exercised. All other BBC staff are appointed by the BBC itself.

The government also has the power to demand that the $\mathrm{BBC}$ broadcast or refrain from broadcasting any particular prograin. The BBC retains the right to announce any program demands or vetoes by the government. The power of the veto has never been used.

Finally, the government has absolute control over the allocation of radio and television broadcasting frequencies. It can limit the number of hours of broadcasting and, as a last resort, can revoke both the BBC's charter and license. J. GABRIEL, THINKING ABOUT Television 81-83 (1973). For more detailed descriptions of the BBC, see T. BURNS, THE BBC: PUBLIC INSTITUTION and Private World (1977); R. Coase, British Broadcasting (1950); T. Green, The Universal Eye 80-102 (1972); B. Paulu, British Broadcasting in Transition (1961); A. SMITH, BRITISH BROADCASTING (1974).

227. The ECONOMist, July 29, 1978, at 13.

228. Steiner, supra note 223. 
produce a program schedule of "excessive sameness." 229 By contrast, a monopolist im control of the same number of channels will produce programming of greater diversity, provided that there does not exist some one program (or program type) that all interest groups will tolerate. $^{230}$

It follows from this analysis that a very great improvement in viewer welfare might result from the monopolization of the three networks by a single commercial organization. ${ }^{231}$ The number of gatekeepers would thereby be reduced from three to one, and the number of viewing options would be unchanged, but the qualitative range of options miglit be vastly increased. In particular, it is not unlikely that the range of political views represented might increase, provided that it was consistent with commercial incentive to appeal to minority-as well as inajority-taste audiences. Monopolization of the network market would, of course, have a detrimental effect on the economic situation of stations and prograin producers, absent some offsetting economic regulation of network prices and profits.

Finally, if a plan of monopolization were implemented from the local level up, it is quite possible that the number of local programs would increase. A local three-channel monopolist might find that local-interest programs attracted audiences not attracted by other prograinming. ${ }^{232}$

\section{Temporal Monopoly.}

The economic theory of program patterns produced by the networks leaves one in a dilemina. Given the existing spectrum allocation decisions (and thus the limited number of channels), and assuming that pay television is impracticable over the air, there seem to be only two policy alternatives, both of which are unattractive. The first is a system in which a few broadcast organizations (local and/or national) compete

229. Id. 220-21.

230. Id. 206-07. Steiner suggests that considerations of common taste in program type inay explain the monopolization of radio in other countries under a public corporation. Id. 207.

It is higlily unhikely that a monopolist could attract virtually the entire viewing population by offering the ultimate common denommator program. Whether sucl a program exists is an empirical matter; some commentators believe that television viewers are very passive. See note 181 supra. If such a program does exist, monopoly could cause a significant decline in viewer welfare.

231. For a discussion of nationalization, see text accompanying notes $239-49$ infra.

232. The principle here is the same as that applied to a monopolist of the network market. A monopolist controlling all three local clrannels would not want to show three programs of the saune type, thereby failing to attract those viewers who would prefer nonviewing to viewing any programs of that type. Thus, while clearing a popular network show on one channel, a local monopohist may broadcast local interest programs on other channels to capture an otherwise nonviewing audience. 
inore or less vigorously for audiences to sell to advertisers, producing programs that may exhibit an "excessive saineness." The second alterative is to use the inechanisms of monopoly to avoid program duplication, but at the price of restricted freedon of expression and possibly with the result of producing only common-denominator programs. ${ }^{233}$

"Temporal monopoly" is a third alternative, one that may-at least in theory-combime the best features of competition and monopoly. ${ }^{234}$ The idea itself is simple. As with temporal disintegration, control of the networks changes over time-as often as the policymaker cliooses. But temporal monopoly adds a fillip: the agent im charge of programming at any given time would control all (three) channels. ${ }^{235}$

The following situation is an example of temporal monopoly. Firm 1 programs all three national network channels every Monday inorning. Firm 2 controls thein every Monday afternoon. Firm 3 controls them every Monday evening. And so on, through firm 21 on Sunday evening. Another example is to have control rotate every hour, witl only four firms in the market. Thus, Firm 1 from 5:00-6:00 p.m.; Firm 2 from 6:00-7:00 p.m.; Firm 3 froin 7:00-8:00 p.m.; Firm 4 from

233. See text accompanying notes $223-25$ supra, and note 230 supra.

234. For a more detailed analysis, see OWEn, BeEbe \& MANNING 132-37.

235. The comparative breakdown of time periods and channels available to broadcasters under different structures - present oligopoly, monopoly and temporal monopoly — is as follows:

PRESENT STRUCTURE

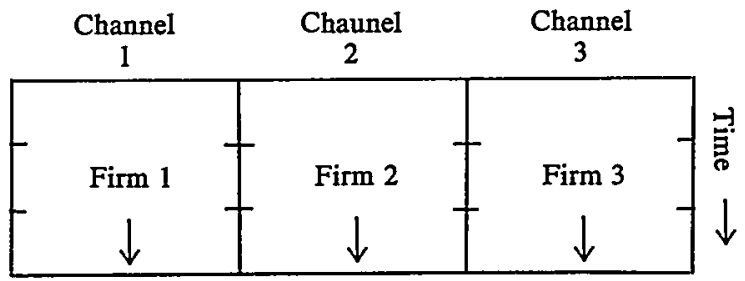

MONOPOLY STRUCTURE

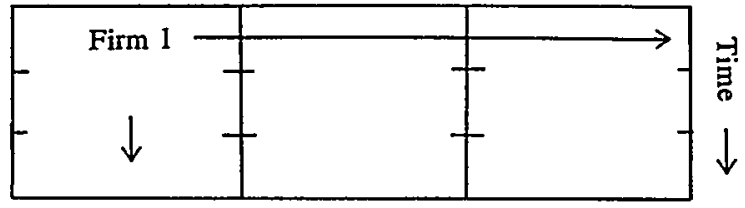

TEMPORAL MONOPOLY STRUCTURE

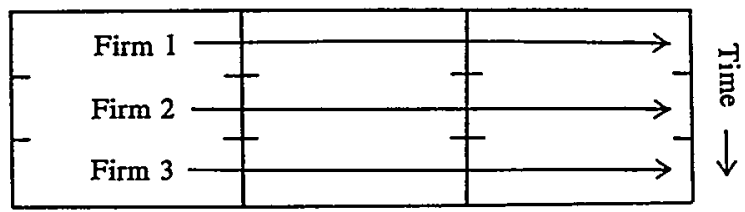

Id. 132 . 
8:00-9:00 p.m.; then Firm 1 again from 9:00-10:00 p.m.; Firm 2 from 10:00-11:00 p.m.; and so on. The choice of number of firms and length of time in control are policy decisions that, while of great practical importance, are not crucial to the underlyimg mechanism.

The advantage of temporal monopoly is that no firm would seek to duplicate programming on channels under its control at a given time, but would instead seek to maximize its audience by appealing to as great a range of interests as the number of channels under its control allowed. At the same time, no firm would control all the channels for a sufficiently long period to present any threat to freedom of expression. ${ }^{236}$ Temporal monopoly would imcrease, or could be used to increase, the number of gatekeepers and thus freedom of expression. While there are clearly practical limits to the number of rotating temporal monopolists, the practical maximum is surely greater than tluree..$^{237}$

Temporal monopoly is a solution designed to cope with the problem of channel scarcity. It does not increase the number of viewing options available to the audience at any one time. However, temporal monopoly is designed to produce an increase im the propensity of broadcasters to cater to minority-taste audiences, and to that extent such a plan could increase program quality in the eyes of some viewers. The result might, but need not necessarily, be an increase in consumer economic welfare.

Temporal monopoly would require that local stations be restructured into the same organizational umits as the national level temporal monopolists. Otherwise, a station that was asked to broadcast a minority-taste program could refuse to clear it, and the scheme would collapse. The effect of temporal inonopoly on local stations would depend on the manner in whicli this problein is resolved. One approach would

236. Under certain theoretical conditions, it can also be said that no common denominator programming would be produced. The conditions are that each viewer must have an upper limit on the amount of his television watching in a particular time span and that limit must be less than the tiune span. For example, if a network controls all channels in a three-hour evening time span, it must be assumed that each viewer will watch no more than two hours of television. Further, viewers must be indifferent to the program periods they watch within the time span. That is, they cannot all go to bed after the second hour. Under these conditions, a temporal monopolist will attempt to maximize the viewing audience in each time period by broadcasting diverse programs to capture different segments of the viewing market that might otherwise opt for nonviewing. For a more complete analysis, see OWEN, BEEBE \& MANNINg 132-36.

237. A minimum policy designed to increase diversity of sources of control over programming, given the relative passivity of affiliates, is to adopt the twenty-one networks proposal. . . . It may be that this is the most technically feasible, practical, and efficacious way in which to create new networks within the current spectrum allocation. It is, however, a proposal that the networks would violently oppose....

Id. 137. 
be to rotate control of all the local channels among existimg local licensees. Thus, the number of local competitors would not be increased, even though the number of national competitors would increase. Local stations-or rather local broadcast firms-would still compete over time for advertisers and audiences. Thus, the proposal nnght benefit local stations if it were designed to do so, while still improving programming on the national level.

The effect teinporal monopoly would have on the program production industry is somewhat ambiguous. The number of buyers in the program inarket would not decrease, but rather would imcrease. Although the number of program hours purchased would not change, the type of programming might change radically as a result of the predicted tendency to cater to minority tastes, thereby reducing demand for presently scarce and therefore highly paid skills and talents. Because the qualitative character of programs would be different under temporal inonopoly, the composition of demand would change and thus subject producers to risks and uncertainties during the transition. An individual program producer might justifiably view temporal monopoly with some alarm because of the risk that her particular talents miglit be in less demand, but the industry as a whole would probably benefit.

Teinporal inonopoly has no clear or necessary effect on local programming or the opportumity for it, except to the extent discussed with respect to the $\mathrm{BBC}$ inonopolization model. ${ }^{238}$

\section{J. Nationalization.}

The BBC system was used as a model for a discussion of monopolization of several channels by a simgle broadcaster, but the BBC model lias additional characteristics that distinguish it from the American system. One of these is the absence of local programs, a trade-off discussed in comrection with the DuMont plan. ${ }^{239}$ Another characteristic is that the $\mathrm{BBC}$ is a nationalized enterprise, dependent for financial support on a government levy on television sets. ${ }^{240}$

Nationalization avoids whatever evils may result from the need to seek large audiences in order to attract advertising revenues. Still, pressures to serve as large an audience as possible may remain; a nationalized industry in a democratic state would not be acting wisely if it

238. See note 232 supra and accompanying text.

239. See text accompanying notes 157-65 supra.

240. T. BURNS, supra note 226, at 7,9. After ending the $1974-75$ financial year with a deficit of $£ 17$ million, the $\mathrm{BBC}$ raised license fees from $£ 8$ to $£ 18$. Id. 224. The $\mathrm{BBC}$ is currently seeking a $40 \%$ increase in license fees. The Economist, July 29, 1978, at 13. 
ignored the size of its constituency. Nationalization as an alternative to excessive private network power has another obvious cost-the opportunity for government intervention in and control of the marketplace of ideas is vastly increased. Most European broadcasting systems are nationalized, ${ }^{241}$ and most observers regard freedom of expression by television in those countries as narrowly circumscribed. ${ }^{242}$

Early in the history of broadcasting im the United States, a number of channels were reserved for what was then designated "educational" television. ${ }^{243}$ The channel reservations were unused or underutilized until the Public Broadcasting Act of 1967 created the Corporation for Public Broadcasting and provided significant federal funding. ${ }^{244}$ Today there exists a nationalized television network, financed (or perhaps underfinanced) fron 1 federal revenues and private donations. ${ }^{245}$ The public broadcasting system has been beset by external and internal political quarrels, ${ }^{246}$ and may be suffering from the lack of a clear objective. ${ }^{247}$

While a public broadcasting service still holds promise, and might be structured along any one of the several lines suggested above, it is arguable that the experiment to date has failed. ${ }^{248}$ If the channels reserved for "educational" television had instead been devoted to cominercial broadcasting, it is likely that a fourth commercial network

241. Noll, PECK \& MCGOWAN 209.

242. See, e.g., B. Paulu, Radio and Television Broadcasting in Eastern Europe 8-11 (1974); J. QuinN, The Film and Television as an Aspect of European Culture 94-95 (1968); Nixon, Freedom in the World's Press: A Fresh Appraisal with New Data, 42 Journalism Q. 3 (1965).

243. FCC Sixth Report and Order, supra note 142, 41 F.C.C. at 158.

244. 47 U.S.C. $\$ \S 390-399$ (1976) (originally enacted as Public Broadcasting Act of 1967, Püb. L. No. 90-129, 81 Stat. 365). Congress appropriated $\$ 9$ million for the Corporation's first year of operation. 81 Stat, at 372.

245. The Secretary of the Treasury administers the Public Broadcasting Fund, which is used for the expenses of the Corporation. Congress inay appropriate to the Fund an aunount equal to $40 \%$ of the total non-federal support received by public broadcasting entities, provided such amount does not exceed $\$ 140$ million for the fiscal year ending Sept. 30, 1979. 47 U.S.C.A. $\S 5396(\mathrm{k})$ (West Supp. 1978).

246. See, e.g., G. Gibson, Public Broadcasting 170-223 (1977); Canby, The First Amendment and the State as Editor: Implications for Public Broadcasting, 52 TEX. L. REv. 1123, 1156-58 (1974); Chase, Public Broadcasting and the Problem of Government Influence: Towards a Legislative Solution, 9 U. Mich. J.L. REF. 62, 82-88 (1975). It has been pointed out that while public broadcasting was founded on principles of insulation from government, of localisin and of financial support from diverse sources, the reality lias been government interference, economic chaos due to the inefficiencies of localism, and a constant shortage of funds with an ever-increasing infusion of federal funds. The Future of Public Broadcasting 2-4 (D. Cater \& M. Nylan eds. 1976).

247. The Carrnegie Commission charged it to pursue "excellence in the service of diversity," Carnegie Commission on Educational Television, Public Television: a Program for ACTION 14 (1967), but presumably not in soap operas.

248. B. OWEN, supra note 53, at 133-34. 
would have developed by now. ${ }^{249}$ The economic welfare associated with giving viewers a fourth commercial network option almost certainly exceeds the welfare associated with public broadcasting in its present form. Moreover, the present system probably benefits relatively wealthy, educated viewers at the expense of the poorer and less educated viewers.

Whetler nationalization would improve matters in terms of the criteria enumerated above is primarily dependent upon the details of the particular structure adopted. One can certainly imagime a theoretical structure under which nationalized television would be consistent with an increase in freedom of expression and consumer welfare. An examination of all the possible alternatives seems poimtless in view of their very large number;

\section{Conclusion}

The proposals for structural cliange considered in this Article differ not only in their effect on the various dimensions in which the public interest miglit be assumed to lie, but also in their underlying assumptions about what is politically feasible. For example, temporal monopoly takes as given the political infeasibility of increasing the number of local signals and stations. For these reasons, it is not possible to provide a ranking of these alternatives according to their desirability from a public policy perspective.

Nevertheless, some general observations can be made. On the whole, there seems to be little conflict between increases in viewer welfare and increases in ease of access to the audience. Greater numbers of gatekeepers and, presumably, greater freedom of expression go hand in hand witl imcreases in the number and quality of program choices. On the other hand, there clearly is a direct conflict between the profitability of local stations and the number of viewing alternatives available to the audience. Thus, the present high profits of VHF networkaffiliated stations really are obtained at the expense of viewers.

Some of the proposals seem liardly worth the effort that would be involved in implementing them. Divestiture of the $O \& O$ stations and geographic disintegrátion seem to fall in this category; their net benefits seeın likely to be small in comparison witl the costs of implementation. Soine of the proposals require suclı massive dislocations of existing vested interests tliat it is difficult to imagine their adoption in the present climate of opinion. The DuMont plan alternative seems to fall into

249. See Crandall, The Eeonomic Case for a Fourth Commercial Television Network, 22 PuB. POL'Y 513, 532-34 (1974). 
this category. But there remain a number of alternatives that have considerable promise and might feasibly be adopted. The choice will depend on the weights assigned to the various policy criteria. One should add that not all of the proposals are mutually exclusive. For example, promotion of cable growth is not incompatible with any of the other proposals. Some cable growth, of course, will come about naturally in any event. While all the possible combinations are too numerous for analysis here, the very fact of compatibility could prove important should the power of an agency to mstitute certam structural remedies be limited by the courts. The desired results might still be obtained through interagency cooperation and implenentation of compatible remedies.

The debate about network power has been focused for too long on the alleged behavioral evils and corresponding administrative solutions. The real "problem" with the television networks is not that they behave badly, but that there are only three of them. There are only three of them because of FCC policy, which centers around political values such as localism. The major cost of this policy is that the television audience is denied that range of choice and quality in programming that a more competitive system would provide. Although structural changes may be costly, they can benefit consuners directly, while behavorial remedies of the sort proposed and debated in the past would serve mainly to reallocate profit annong these industries or industry segments without improving viewer welfare. 